NBER WORKING PAPER SERIES

INNOVATION, GROWTH AND STRUCTURAL CHANGE IN AMERICAN AGRICULTURE

\author{
Julian M. Alston \\ Philip G. Pardey \\ Working Paper 27206 \\ http://www.nber.org/papers/w27206 \\ NATIONAL BUREAU OF ECONOMIC RESEARCH \\ 1050 Massachusetts Avenue \\ Cambridge, MA 02138 \\ May 2020
}

The authors are grateful for the excellent research assistance provided by Connie Chan-Kang, Xudong Rao and Shanchao Wang, for helpful advice provided by James (Jess) LowenbergDeBoer, Abigail Okrent, J.B. Penn, and David Schimmelpfennig, and for helpful comments provided Brian Wright, other participants in the Symposium, and the organizers. The work for this project was partly supported by the California Agricultural Experiment Station; the Minnesota Agricultural Experiment Station (MIN-14-161); the USDA National Research Initiative; and the Giannini Foundation of Agricultural Economics. The views expressed herein are those of the authors and do not necessarily reflect the views of the National Bureau of Economic Research.

NBER working papers are circulated for discussion and comment purposes. They have not been peer-reviewed or been subject to the review by the NBER Board of Directors that accompanies official NBER publications.

(C) 2020 by Julian M. Alston and Philip G. Pardey. All rights reserved. Short sections of text, not to exceed two paragraphs, may be quoted without explicit permission provided that full credit, including $\odot$ notice, is given to the source. 
Innovation, Growth and Structural Change in American Agriculture

Julian M. Alston and Philip G. Pardey

NBER Working Paper No. 27206

May 2020

JEL No. O13,O3,O4,O51,Q16,Q28,Q52

\begin{abstract}
$\underline{\text { ABSTRACT }}$
U.S. agriculture was transformed during the 20th century by waves of innovation with mechanical, biological, chemical, and information technologies. Compared with a few decades ago, today's agriculture is much less labor intensive and farms are much larger and more specialized, supplying a much-evolved market for farm products. Over recent decades, the global landscape for agricultural R\&D has shifted away from farms, away from the public sector toward the private sector, and away from the United States towards agriculturally important middleincome countries, especially China, India and Brazil. U.S. investments in agricultural R\&D are stalling even though meta-evidence shows that past U.S. investments in agricultural R\&D have yielded very favorable returns: median reported benefit-cost ratios in the range of 12:1. Sustained U.S. investment and innovation will be required to preserve past productivity gains in the face of climate change, coevolving pests and diseases, and changing technological regulations-let alone increase productivity. Great potential exists for innovation in crop and livestock genetics and digital farming technologies to generate new products and production processes, but innovators are facing increasingly strong headwinds from social and political forces that seek to dictate technology choices.
\end{abstract}

Julian M. Alston

University of California, Davis

julian@primal.ucdavis.edu

Philip G. Pardey

University of Minnesota

ppardey@umn.edu 


\section{Innovation, Growth and Structural Change in American Agriculture}

Julian M. Alston and Philip G. Pardey

ABSTRACT. U.S. agriculture was transformed during the 20th century by waves of innovation with mechanical, biological, chemical, and information technologies. Compared with a few decades ago, today's agriculture is much less labor intensive and farms are much larger and more specialized, supplying a much-evolved market for farm products. Over recent decades, the global landscape for agricultural $R \& D$ has shifted away from farms, away from the public sector toward the private sector, and away from the United States towards agriculturally important middle-income countries, especially China, India and Brazil. U.S. investments in agricultural R\&D are stalling even though meta-evidence shows that past U.S. investments in agricultural R\&D have yielded very favorable returns: median reported benefit-cost ratios in the range of 12:1. Sustained U.S. investment and innovation will be required to preserve past productivity gains in the face of climate change, coevolving pests and diseases, and changing technological regulations - let alone increase productivity. Great potential exists for innovation in crop and livestock genetics and digital farming technologies to generate new products and production processes, but innovators are facing increasingly strong headwinds from social and political forces that seek to dictate technology choices.

Keywords: U.S. agriculture, R\&D and productivity, biotechnology; digital technology; precision agriculture; technological regulation 


\section{Introduction}

During the $20^{\text {th }}$ century American agriculture was dramatically transformed and its role in the economy changed markedly. The progressive introduction and adoption of a host of technological innovations and other farming improvements enabled much more to be produced with less land and a lot less labor; farms became many fewer, much larger, and more specialized. However, while agriculture continued to grow, it shrank in relative importance. The U.S. farm population peaked at 32.5 million, $31.9 \%$ of the total U.S. population in 1916; since then it declined to an estimated 4.5 million in 2019 , just $1.4 \%$ of the total. And, while agriculture's contribution to GDP increased (somewhat erratically) from $12 \%$ in 1889 to $17 \%$ in 1917 , it declined steadily thereafter to just $0.81 \%$ in 2018 . Innovation on and off farms played a central role.

This paper provides detailed documentation, evidence, and analysis of the past and ongoing sources of innovation and structural change in American agriculture. To begin, we describe the profound structural transformation of American agriculture over the course of the past century, and the implications for changing patterns of inputs, outputs, and productivity. Then we turn to a consideration of the sources of change. We pay particular attention to the impact of innovation as a driver of productivity and employment in the agricultural sector; to the role of private entrepreneurship in the process; and to the distinctive features of the agricultural sector-still largely atomistic and heavily dependent on a host of natural, often location-specific, inputs, changes in which can undercut past productivity gains - and its evolution (shrinking as a share of the economy). Digging deeper, we present evidence on inputs to and outputs from innovation, on the resulting gains in productivity, what those gains are worth, prospects for the coming decades, hurdles to be overcome, and roles played by government policies. 
Before getting into the meat of this chapter, we briefly broach some conceptual, measurement and other data issues that are integral to the structural changes we are studying. Over time farms became increasingly specialized in a narrower range of market goods. Many productive activities progressively shifted off farms - to be undertaken by specialized (pre-farm) agribusiness firms that nowadays produce farm machinery, seed, chemicals, energy, and other inputs-including contract services - that were once largely (and in some instances entirely) produced on-farm; likewise farm households once made many food and fiber products that are now produced entirely off-farm by agribusiness firms in other (post-farm) sectors of the economy. ${ }^{1}$ These shifts have implications for where the lines are drawn in distinguishing between farms and other firms and thus between agriculture and the rest of the economy.

In industrial organization parlance, farms and farmers are now less vertically integrated and more specialized, the nature of the farm firm has changed (Coase 1937). So, too has the statistical definition of a farm - whether specified in terms of acres farmed, the value of sales, or some combination of the two. ${ }^{2}$ The large changes over the decades in the actual and recorded nature of farms and farming pose challenges for economists who measure inputs and outputs and seek to make intertemporal comparisons. Moreover, the data are not always collected and presented in the preferred ways that make it possible to develop consistent measures that match the conceptual constructs. Nonetheless, the available measures are informative.

\footnotetext{
${ }^{1}$ These include a shift from a world in which farmers would themselves produce energy and traction for farm operations and fertilizer for crops (using horses and mules), seed and other inputs, as well most if not all of their own food, to a world in which most of those inputs and outputs are now purchased off farm.

${ }^{2}$ As discussed by Sumner (2014), concepts of farm firm size based on land area, that might work well for cropping farms in the U.S. Midwest, are less useful for intensive livestock producers or horticulture where gross value of sales, total employment of labor, or total value of the capital stock - as sometimes used to measure size of non-farm firms - might be more useful. Issues surrounding the statistical definition of what is a farm are linked with issues about how to measure farm size since many of the USDA definitions, which themselves have changed from time to time, are based on a farm size criterion involving area or value-of-sales attributes.
} 
The data issues associated with the changing structure of agriculture and the distinction between agriculture and other sectors of the economy extend to the corresponding concepts and measures of public and private investments in agricultural and food R\&D. In our discussion of these issues we take pains to place agricultural R\&D spending in the context of broader measures of public and private R\&D, maintaining a consistent set of definitions of agricultural versus nonagricultural, and private versus public as used by other publications dealing with these concepts applied to R\&D. A perennial challenge in this context is how to treat more fundamental scientific inquiries, the ultimate application of which by definition remains to be seen. Discussions of spillovers and attribution often entail assumptions that are hard to validate. Where possible we address these aspects.

\section{Special Features of Agriculture ${ }^{3}$}

Innovation in agriculture has many features in common with innovation more generally, but agriculture differs in terms of its industrial structure and the nature of market failures in innovation; the spatial dimensions of production and the site-specific nature of the technology; the biological nature of the production process; and the nature of food and farming as perceived by the broader public and groups that define technological regulations and requirements. It is helpful to have those differences in mind as we review the past and prospective changes in agriculture and the roles of entrepreneurship and innovation in shaping them.

Like other parts of the economy, agriculture is characterized by market failures associated with incomplete property rights over inventions. The atomistic structure of much of agriculture means that the attenuation of incentives to innovate is more pronounced than in other

\footnotetext{
${ }^{3}$ Parts of this section draw from Pardey et al. (2010).
} 
industries that are more concentrated in their industrial structure. On the other hand, unlike most innovations in manufacturing, food processing, or transportation, agricultural technology has a degree of site specificity because of the biological nature of agricultural production, in which appropriate technologies vary with changes in climate, soil types, topography, latitude, altitude, and distance from markets. The site-specific aspect circumscribes the potential for knowledge spillovers and the associated market failures that are exacerbated by the small-scale, competitive, atomistic industrial structure of much of production agriculture.

Agriculture is further distinguished by the biological and spatial nature of its production technology (Joglekar et al. 2016). Agricultural production takes up a lot of space—indeed, about $40 \%$ of the world's land area is occupied by agriculture (including $12 \%$ used for crops) and $44 \%$ of U.S. land is in agriculture- and the nature of the space varies in ways that are relevant for the choice of technology and the returns to innovations that are often very site-specific. The biological nature of agricultural production means that production processes take time, during which outcomes are susceptible to the influence of factors such as weather and pests that are difficult or costly to control. Moreover, the agricultural production consequences of pests and weather vary in ways that are often uncontrolled and difficult to predict with present knowledge and technology, not only within a season but systematically over time and space. Climate change and the co-evolution and adaptation of pests and diseases mean maintenance research is required to prevent yields from declining — the "Red Queen" effect as discussed by Olmstead and Rhode (2002) for instance. ${ }^{4}$ These features of agriculture give rise to a demand for innovations that reduce the susceptibility of production to uncontrolled biotic and abiotic stresses and allow

\footnotetext{
${ }^{4}$ For example, a 1986 survey of 744 U.S agricultural scientists suggested that "maintenance research" accounted for around one-third of production-oriented agricultural research at that time (Adusei and Norton 1990).
} 
technology to adapt to changes in the farming environment or changes in technological regulations.

Agriculture is also subject to different kinds of public and policy scrutiny because, compared with most other industrial outputs, people care differently about food and the way it is produced, and increasingly so as they become richer. U.S. consumers are increasingly demanding foods that have "credence" attributes associated with the products and the processes used to produce them — such as organic, locally produced, and raised using humane livestock and poultry practices (see, e.g., Rausser et al. 2015, 2019). Alston (2019) discusses this demand and the related demand for technological regulation coming from what he terms the "woke farm and food policy reform movement," which blames the agricultural and food industry for various societal ills (see, e.g., Willet et al. 2019). Some food processors, manufacturers, and retailers are requiring foods to be produced in ways that accommodate these demands (see, e.g., Saitone et al. 2015). All these forces have implications for the types of innovations that will be relevant for American farms in the coming decades - as they or forces like them were in the past.

\section{Structure of American Agriculture}

Land-saving and especially labor-saving innovations were central to the structural transformation of American agriculture in the 20th Century. The number of U.S. farms grew from 1.4 million in 1850 to a peak of 6.8 million in 1936 before falling to 2.9 million in 1970 and 2.1 million in 2017; land in farms peaked in 1954 (Figure 1; Pardey and Alston 2019). Farms became much larger and more-specialized in terms of their output mix, and the input mix 
shifted to use much less labor and a little less land, combined with more capital and purchased material inputs. ${ }^{5}$

[Figure 1: U.S. Farm Area and Farm Numbers, 1850-2017]

\section{Farm Labor}

These changes in the structure of agriculture entailed changes in the structure of the farm labor force, reflecting both the pull from growth in non-farm demand for labor, driving up the opportunity cost of farmers' time as well as the cost of hired farm labor, and the push from technological changes on farms that permitted more to be produced with much less labor and more land per farm. Farmers responded to these incentives and opportunities by consolidating farms and substituting other inputs for labor, in part by developing and adopting labor-saving innovations that favored higher land-labor ratios and larger optimal farm sizes. ${ }^{6}$ Figure 2 captures the main elements of the post-WWII changes in farm labor use. In panel a, total labor use - measured in hours per year, and taking account of the major shift to part-time farming —in

\footnotetext{
${ }^{5}$ These aggregate figures encompass highly diverse farm sizes and types. In 1920, the United States had 735 million acres on 6.4 million farms, at an average of 8.7 acres per farm. None of those farms had more than 1,000 acres. By 2012, the total number of farms had fallen by more than two-thirds compared with 1920 . Now $9.2 \%$ of a total 2.1 million farms had more than 1,000 acres. Notably, more than $10 \%$ of today's "farms" have less than 10 acres, but many of today's small farms are "hobby farms," and many are part-time occupations for people for whom living on a farm is a life-style choice more than a way of making a living.

${ }^{6}$ MacDonald et al. (2018) report that "By 2015, 51 percent of the value of U.S. farm production came from farms with at least \$1 million in sales, compared to 31 percent in 1991 (adjusted for price changes) ... . [Now] few farms specialize in a single crop, field crop operations increasingly grow just 2 or 3 crops, versus 4-6 crops previously. Livestock production continues to shift toward farms that produce no crops, and instead rely on purchased feed.... Despite increased consolidation, most production continues to be carried out on family farms, which are owned and operated by people related to one another by blood or marriage. Family farms accounted for 90 percent of farms with at least \$1 million in sales in 2015."
} 
agriculture fell by two-thirds, from 1949 to 2007 . Within this total, operator labor fell by more than three-quarters and the hired labor share increased from $20 \%$ to $32 \%{ }^{7}$

[Figure 2: Labor Use in U.S. Agriculture, 1949-2007]

As farmers substituted other inputs for more-expensive labor the cost share of labor fell from more than $42 \%$ in 1949 to less than $30 \%$ in 2007 . Mainly, farmers increased their use of materials inputs purchased off farm (such as seed, fuel, electricity, fertilizer and other agricultural chemicals, and hired machines); the total use of land and capital (measured with appropriate indexes) remained relatively constant—albeit with considerable variation in these details over time and among states. ${ }^{8}$ The mix of agricultural output has also changed over time, reflecting the effects of changes in U.S. and foreign demand for U.S. farm products, as well as the effects of changing production possibilities enabled by new technologies. ${ }^{9}$ The category of nursery and greenhouse marketing in particular has grown rapidly, and constituted the fastest growing category of output for all but five of the 48 contiguous U.S. states during the second half of the $20^{\text {th }}$ century (Alston et al. 2010, p. 69). ${ }^{10}$

\footnotetext{
${ }^{7}$ Growth of the rural non-farm economy has facilitated growth in off-farm employment for farm household members. Between 1930 and 2012, the share of full-time farm operators fell from $70 \%$ to $40 \%$ and their average number of days per year worked off-farm increased from 86.5 to 143.2.

${ }^{8}$ Alston et al. (2010) provide detailed state-level and national data on inputs, outputs, and productivity in U.S. agriculture during the period 1949-2002 in a book-length treatment. State- and national-level data for the period 1949-2007 are available on the InSTePP website (see Pardey et al. 2006 for data documentation), and discussed by Pardey and Alston (2019).

${ }^{9}$ Among other changes, improved communications, electrification, transportation, and logistical infrastructure, meant that perishables and pre-prepared foods could be moved efficiently over much longer distances. This contributed to the changing spatial patterns of production.

10 "Nursery and greenhouse marketing" produces ornamental and diverse other plants and has grown in comparative importance as Americans have become more affluent. Much of it is highly intensive horticulture, often located in the urban fringe, and probably lies outside common and traditional perceptions of "agriculture." But it counts as part of agriculture in official agricultural statistics and other manifestations of agricultural policy-whereas golf courses and forestry, for example, do not - and in many instances this is as good a basis as any we may have for drawing the distinction between what we reasonably should or should not count as part of the sector. The essential idea is "agriculture" is economic activity that happens on farms. As the balance of that activity has changed,
} 


\section{Agricultural Productivity}

Reflecting these and other changes, over the past 100 years and more U.S. agricultural productivity grew rapidly — albeit unevenly over time and across states. Over the period 19102007, multifactor productivity (MFP) in U.S. agriculture grew at an average annual rate of $1.42 \%$, reflecting average annual growth of $1.58 \%$ in the index of aggregate output and $0.16 \%$ in the index of inputs. These averages reflect shrinking total inputs (and even total output) in some states as they shifted out of agriculture, contrasted by comparatively rapid expansion in inputs and output in some other states. And they also reflect changes in the composition of inputs and outputs, as already discussed. Since WWII, MFP has grown generally rapidly in U.S. agriculture, but this reflects a surge (during the 1950s-1980s) followed by a slowdown such that MFP has been growing at about 1\% per year since 1990, compared with about 2\% per year during 1950-1990 (see Andersen et al. 2018, and Pardey and Alston 2019). ${ }^{11}$

[Table 1: Growth Rates in U.S. Agricultural Input, Output, and Productivity 1910-2007]

\section{Off-farm Changes}

The pre-and post-farm elements of the farm-based food and fiber supply chain have also been transformed, especially during the past half century. The pre-farm agribusiness industries that supply inputs used by farmers, many of which embody technological innovations - whether genetic, chemical, mechanical, or digital — have become more concentrated, more global, and

\footnotetext{
implicitly the concept and measures of agriculture have evolved in ways that make consistent intertemporal comparisons harder.

${ }^{11}$ This raises questions about the relative productivity performance of agriculture compared with other sectors of the U.S. economy. Following Jorgenson and Gollop (1992) it has become a stylized fact among agricultural and other economists to say productivity has grown comparatively quickly in agriculture. That may well have been true during the surge, but is less likely to be so since the slowdown. Consistent, comparable measures in suitably long time series are not readily available to permit definite answers to these questions, which are the subject of continuing study.
} 
more vertically integrated, while accounting for an increasing share of total value added by the sector (Figure 3). The post-farm sector, likewise has become more concentrated and more economically important, such that the farming sector represents an ever-shrinking share of the total food value chain. In 2017, the average farm share was down to 14.6 cents per dollar of food expenditure by consumers (USDA-ERS, 2019).

[Figure 3: Concentration in the Food Retailing Sector]

The income elasticity of demand for food per se is quite low for most Americans (see, e.g., Okrent and Alston 2011), but the demand for services associated with food and other "quality" attributes of food is much more income elastic. With rises in per capita incomes and the opportunity cost of time- - especially for women as they have progressively entered the workforce-Americans have increasingly demanded more food away from home (accounting for more than half of food expenditure and more than one-third of calories since 2010) and more prepared foods and ready-to-eat foods for consumption at home (Okrent et al. 2018, Saksena et al. 2018) (Figure 4). In addition, they are demanding food differentiated in various ways according to both product attributes (related to nutrients, food safety, and so on) and process attributes (related to technologies used on farms such as genetically engineered varieties, organic practices, pesticide use, animal husbandry practices, and so on).

\section{[Figure 4: Food Expenditures at Home and Away from Home]}

The choices of technologies available to farmers and the types of food products available to consumers are increasingly being mediated by the food processing, manufacturing, and retailing sector (e.g., Saitone et al. 2015), cognizant of the evolving consumer marketplace and the influence of activist organizations (Rausser et al. 2015, 2019; Alston 2019). Indeed, private regulation of farm technologies imposed by food manufacturers and retailers might come to 
supplant government regulation in this domain. In turn, these shifts have implications for the demand for technologies expressed by farmers and the derived demand for investment in R\&D and innovation, and ultimately these processes will shape the future path of demand for farm inputs, supply of farm outputs, productivity, and prices.

\section{Investments in Innovation}

Farmers are tinkerers. The 10,000 year history of agriculture and agricultural innovation includes only a century or two of organized science and other institutions that foster innovation (Ruttan 1982; Pardey et al. 1991). In the United States, since 1862 — which marked both the establishment of the U.S. Department of Agriculture (USDA) and the passage of the Morrill Land Grant College Act—state and federal governments have become progressively more involved through both public investments in and the public performance of food and agricultural R\&D. So too has the private sector, especially in more recent decades as the incentives for investing in food and agricultural innovation have strengthened. In particular, changes in intellectual property (IP) protection enhanced the appropriability of the returns to biological innovations as more fundamental discoveries in the basic biological sciences opened up new (applied) R\&D possibilities.

Food and agricultural innovation investments also evolved in conjunction with, benefited from, and contributed to R\&D spending directed to other sectors of the economy. During the past half century, the patterns of R\&D spending overall (or gross domestic expenditures on R\&D, GERD) and R\&D spending directed to the food and agricultural sector (or agGERD) have continued to change in ways that we quantify and discuss in this section. 


\section{GERD versus agGERD}

In 1953 the United States economy invested \$34.4 billion (2011 prices, and likewise below unless otherwise stated) in total (public and private) research and development (R\&D). Over the subsequent six decades, GERD in deflated terms grew 13.5 -fold (or $4.2 \%$ per year on average) to total $\$ 465$ billion in 2015 (Figure 5, Panel a). Over this same period, public and private investments in food and agricultural R\&D carried out in the United States also grew markedly — albeit at a slightly slower average annual rate of $3.7 \%$ per year, again in constant prices_-from $\$ 1.27$ billion in 1953 to $\$ 12.6$ billion in 2015 (Figure 5, Panel b).

[Figure 5: GERD versus agGERD spending trends, 1950 - 2015]

As a consequence of these differential rates of R\&D spending growth, the share of food and agricultural R\&D (agGERD) in total GERD gradually trended down from $3.7 \%$ in 1953 to $2.7 \%$ in 2015 , in tandem with the secular decline in the agricultural share of overall economic activity. However, while the agGDP/GDP ratio shrank in a reasonably steady fashion, the reduction in the agricultural share of total R\&D was less regular. Overall U.S. spending on R\&D grew faster than spending on agricultural R\&D during the 1950s. During the agricultural productivity surge of the 1960s and 1970s, spending on agGERD grew substantially faster than spending on GERD such that the food and agricultural share of total R\&D spending peaked in 1977 at $4.2 \%$ (versus $2.5 \%$ in 1961). Thereafter, GERD grew faster than agGERD, such that by 2015 the food and agricultural share of GERD had reverted to the low point of the early 1960s.

Although the food and agricultural share of GERD has gradually declined over recent decades, the food and agricultural sector continues to invest more intensively in R\&D than does the U.S. economy as a whole. Investments in food and agricultural R\&D when expressed relative to agGDP grew steadily from just $0.7 \%$ in 1950 to a peak of $9.2 \%$ in 2002 , shrinking 
thereafter to $7.7 \%$ in 2015 (Figure 6). At $2.75 \%$ in 2015 , the economy-wide intensity of R\&D investments in the United States was half the corresponding food and agricultural research intensity, and roughly equivalent to the intensity of GERD investment that prevailed half a century earlier (i.e., $2.79 \%$ in 1964).

[Figure 6: The Intensity of Investment in GERD versus agGERD, 1950 - 2015]

\section{Private versus Public Research}

The private sector has long accounted for a significant share of U.S. GERD, averaging $70.2 \%$ of the total since 1953 , albeit with a period during the $1960 \mathrm{~s}$ and $1970 \mathrm{~s}$ when the share of private $R \& D$ investments fell well below the long run average, bottoming out at $65.7 \%$ in 1975 (Figure 5, Panel a). While the private share of food and agricultural R\&D (70.0\% in 2015) is now roughly in line with the private share of research overall, this is a relatively recent development, with the private sector accounting for just over one-third of U.S. food and agricultural R\&D in the early 1950s (Figure 5 , Panel b).

Changes in the scope of U.S. IP protection were associated with a rise in agricultural innovations coming from the corporate sector. Mechanical, chemical, storage, transport and processing inventions pertinent to food and agriculture have long been subject to patent protection (as well as copyright, trademark, trade secrecy and eventually other legal means) enabled by Article 1, Section 8 of the U.S. Constitution that became operational on March 4, 1789. However, little protection was afforded biological inventions such as new crop varieties (likewise for genetics-related innovations in the health sector). Trademarks and trade secrecy laws were applicable, but these did not protect against reverse engineering or self-replication, 
and so the common practice of saving seeds for own reuse - or for sharing with other farmers or selling to them - did not constitute legal infringement of new seed varieties.

It was not until 1930 that legal forms of plant varietal rights were on offer in the United States, and the corporate share of such rights issued rose from 55\% in the 1930s and 1940s to 82\% by 2008 (Pardey et al. 2013). The 1930 Plant Patent Act covers asexually reproduced plants, a category that largely encompasses ornamental plants and fruits. Sexually reproduced crops, a category that includes grains, oilseed crops and grasses, gained IP protection in 1970 by way of the Plant Variety Protection Act (PVPA). A third form of protection became possible in 1980 with Diamond v. Chakrabarty, in which the U.S. Supreme Court narrowly found that "anything under the sun that is made by man" is patentable subject matter (Wright et al. 2007). In practice, this case and subsequent legal rulings clarified that plant varieties, parts of plants, genetically engineered organisms and gene products themselves were eligible for the same U.S. utility patents that cover most other inventions.

This IP landscape evolved hand-in-hand with important changes in the genetics and genomics sciences that support crop varietal development, notably mechanical (Taylor and Fauquet 2002) and bacterial (Gelvin 2003) means of manipulating genes to produce genetically engineered crops, or more recent, more precise, and more cost-effective means to edit genes such as TALEN and Crisper-Cas9 technologies (Balten et al. 2017). The legislative and legal changes that gathered momentum in the 1970s and 1980s (Pardey et al. 2013) preceded a substantial rise in the amount of private research oriented towards biological innovations during the subsequent decades by firms such as Monsanto (acquired by Bayer in June 2018) and Pioneer-Dupont (now Corteva Agrisciences). 
In addition, over the past 50 years food, beverage, and tobacco processing and manufacturing R\&D has continued to be a big part of total U.S. private spending on food and agricultural R\&D (averaging $42.2 \%$ over the past two decades) as industry has sought to respond to changing consumer demands, including an increase in the share of food and beverages consumed away from home and the desire for prepared foods and those packaged in more convenient forms (Figure 4).

Notably, the more expansive IP protection afforded the food and agricultural sector in the past few decades was associated with a continuing increase (albeit at a slower rate) in the intensity of private food and agricultural R\&D, while the intensity of public agGERD has trended down over the past 15 years (Figure 6, Panel b). In contrast, the intensity of public GERD has changed little since the mid-1960s, such that most of the increase in overall GERD intensity since the late 1970s is attributable to an upward trend in the intensity of private investments in R\&D (Figure 6, Panel a).

These overall intensities mask considerable differences among sectors in the intensity of R\&D investment by private firms. Table 2 reports aggregate firm sales and R\&D spending data grouped into sectors, along with their corresponding intensity of investments (here measured relative to their net domestic sales). Pharmaceutical and medical firms, on average, spent $\$ 12.9$ on $R \& D$ for every $\$ 100$ of sales in 2015 , while chemical companies averaged $\$ 6.7$ and information-related companies $\$ 5.9$, making them the three most R\&D-intensive sectors in the NSF compilation. The InSTePP compilation of data on 132 firms undertaking research related to food and agriculture had an R\&D intensity that averaged 1.2\% in 2014 (Lee et al. 2020). ${ }^{12}$ But

\footnotetext{
${ }^{12}$ InSTePP is the International Science and Technology Practice and Policy center at the University of Minnesota, details of which are at www.instepp.umn.edu.
} 
the intensity of research varied markedly among categories of firms within that sector. Although total sales for food companies were more than double those of agricultural companies in 2014, food companies invested less in $R \& D$ such that their intensity ratios averaged just $0.7 \%$, versus $2.6 \%$ for agriculture-related companies. Nonetheless, these data place food companies on par with "other non-manufacturing companies" in terms of their R\&D intensities, while the intensity of research investments by agricultural companies exceeds those of the automobile, other manufacturing, other chemical, and finance sectors.

[Table 2: Company sales and R\&D intensity, 2014/15]

While the increasing investments in innovation by private (food and agricultural) firms have obviated the need for some public research, much of the private research stands firmly on the shoulders of publicly performed research. ${ }^{13}$ The different roles played by public and private research are revealed to some extent by the substantial differences in the composition of the research performed by the two sectors. Around $40 \%$ of the food and agricultural research performed by the public sector in the period 2007-2009 was considered "basic" research (USDA-CRIS 2020), where the notional objective is the pursuit of new knowledge or ideas without specific applications in mind (OECD 2015, p. 29). Another 48\% of public research was classified as "applied," or research done to meet a specific need. Only $12 \%$ was deemed "developmental" and directed towards the production of specific products and processes with nearer-term commercial potential. This squares with the "basic" research share (44\% in 2015) of public GERD (NSB 2018, Table 4-3). In contrast, 78\% of private GERD, was "developmental"

\footnotetext{
${ }^{13}$ See Fuglie and Schimmelpfennig (2000) and Pardey and Beddow (2013) for examples of public-private research complementarities in the food and agricultural sector.
} 
in nature intended to develop prototypes, new processes, or products for commercialization, with only $16 \%$ of private research considered applied, and $6 \%$ basic.

While clear statistical guidelines for collecting and compiling R\&D statistics (see, e.g., OECD 2015) are widely accepted, the practical application of those guidelines is tricky and involves choices that have implications for the resulting measures and their interpretation. Pardey et al. (2016) provide a detailed description of the conceptual and practical methods they used to identify the "food and agricultural R\&D" series reported here, as distinct from $R \& D$ (or other related activities) performed for other purposes; the sector (e.g., business enterprise, government, higher-education and private non-profit) associated with the performance of the research; and the geographical jurisdiction of the research.

Thus, for example, the private U.S. food and agricultural R\&D series reported here represents R\&D purposely targeting food and agriculture, where the research is performed by business enterprises in the United States, whether by domestic or foreign-owned firms. (An alternative measure could include all private food and agricultural R\&D performed by firms headquartered or operating in the United States, irrespective of where in the world the research occurred.) Creating this series often requires parsing research spending totals into U.S. versus rest-of-world components, a distinction that is increasingly difficult to make as many large multinational companies (U.S.-based and foreign) continue to diversify their R\&D activities globally, but only report total company-wide spending. Moreover, business activities of some firms are only partially associated with the agricultural and food sectors, or span multiple subsectors within the general scope of food and agricultural research. For example, a single firm may undertake chemical research (only some of which is related to food and agriculture) and also undertake biological or varietal development research related to agriculture, and the mix of 
that research may change over time. For this subset of firms, absent any other information the U.S. private-sector series reported here was developed from firm specific data, where, if required, each firm's total R\&D spending was parsed in line with the share of that firm's sales associated with its agricultural or food-related business segments.

\section{International Dimensions of U.S. Research}

In 1960, the United States accounted for $18.6 \%$ of the entire world's expenditures on publicly performed food and agricultural R\&D, but by 2015 that share had shrunk to $9.4 \%$ and the United States was eclipsed by China, which by 2013 had begun outspending the U.S. on both public and private food and agricultural research (Chai et al. 2019). Part of this shifting research geography reflects policy choices in the United States versus China and other countriesespecially other large agricultural economies such as Brazil and India—regarding public spending and other forms of legislative support for agricultural R\&D. These changing international R\&D relativities also reflect more fundamental economic forces shaped by major changes in the economic geography of agriculture itself (Pardey et al. 2016).

In 1961, the United States accounted for $14.8 \%$ by value of the world's agricultural output, compared with China's 8.5\%. Less than six decades later the tables had turned. The U.S. share of global agricultural production had declined to $10.0 \%$ in 2016 , while China now accounted for almost one-quarter $(23.7 \%)$ of the total, propelled by historically unprecedented and sustained rates of growth in Chinese agricultural production and productivity. These Chinese agricultural developments were enabled by several radical institutional reforms beginning in the late 1970s; notably the introduction of the household responsibility system for farming that incentivized farmers to increase output and spurred the off-farm migration of labor (Lin 1992), and the doubling down on investments in agricultural R\&D (Chai et al. 2019). 
Meanwhile, the U.S. government first slowed and then of late scaled back public support for agricultural R\&D.

These shifts in the global landscape for food and agricultural R\&D also paralleled broader changes in the world's economic geography and the country composition of global GERD. In 1980, the United States accounted for $19.8 \%$ of the world's $\$ 6.4$ trillion (2009 PPP prices) GDP, compared with $2.1 \%$ for China. By 2014, while global GDP had grown to $\$ 99.3$ trillion the U.S. share had shrunk to $16.2 \%$ and China's had grown to $16.9 \%$. Dehmer et al. (2019) estimated that over this same period, global GERD had grown from $\$ 0.48$ trillion in 1980 to \$1.67 trillion in 2014 (2009 PPP prices), the U.S. share of global GERD had declined a little from 31.2 to $27.0 \%$, while China's share had increased dramatically from 1.2 to $20.0 \%$.

Where in the rest-of-the-world agricultural $R \& D$ takes place matters as much as the amount and types of research conducted in the United States for the innovative future of U.S. agriculture. Just as genetic innovations conceived in the health sector have benefited agriculture (and vice versa), rest-of-world agricultural knowledge stocks have spatial spillover consequences for U.S. agriculture (see, e.g., Clancy et al. 2020). However, space matters more for agriculture, and many agricultural innovations are site-specific. Consequently, taking wheat as an example, research targeted for agroecologies (or production systems) that are agroecologically distant from current or prospective wheat areas in the United States, are likely to be less consequential for wheat innovation in the United States than if they were targeted to U.S. agroecologies. ${ }^{14}$ Thus, with an increasing share of the world's agricultural research taking place outside the

\footnotetext{
${ }^{14}$ At any given point in time hundreds of different wheat varieties are being grown or bred that are adapted to specific agroecologies, and the productive potential of any particular variety of wheat varies greatly depending on where in the world, precisely, that variety is to be grown.
} 
United States, the global stock of scientific knowledge can be expected to have less relevance for innovations within U.S. production agriculture in the decades ahead relative to decades past. ${ }^{15}$

\section{Payoffs to Investments in Agricultural Innovation}

In the economic evidence on the payoffs to investment in $R \& D$ various summary statistics have been used to summarize the streams of costs and benefits associated with R\&D activities that typically take (sometimes considerable) time for the research to be conducted, and years if not decades for the resulting innovations to diffuse and realize economic consequences. For the most part, however, the internal rate of return (IRR) has been used as the statistic of choice. This is true, for example, for researchers summarizing the economic consequences of manufacturing R\&D (see the tabulation in Hall et al. 2010, Table 2) and health-related research (e.g., HERG et al. 2008; Deloitte 2014; Glover et al. 2014). Notwithstanding Griliches' (1958) objection to the use of IRRs in this context, it is also the preferred summary statistic for the now extensive literature on the returns to agricultural R\&D, which he initiated. ${ }^{16}$

The InSTePP agricultural returns-to-research database (version 3) includes 3,426 rate-ofreturn estimates gleaned from 492 studies worldwide, of which 1,298 (37.9\%) of the estimates evaluate research conducted in the United States (Rao et al. 2019a). Among the U.S estimates,

\footnotetext{
${ }^{15}$ As discussed by Alston (2002) and emphasized by Alston et al. (2010), agricultural technology spillovers are significant, and run in both directions, though not always symmetrically or spontaneously. Cognizant of this fact, private foundations based in the United States together with the U.S. government led the funding (as well as the founding) of the system of international agricultural research centers now known as the CGIAR. This institutional innovation was conceived for essentially humanitarian purposes to address the global food crisis of the 1960s, and was a primary source of the so-called "Green Revolution" technologies (see, e.g., Alston et al. 2006 and Wright 2012). It reduced but did not eliminate a global market failure in agricultural R\&D that persists today. The donor countries also benefited by adopting the resulting technologies, as quantified, for example, by Pardey et al. (1996) in relation to the spillins of CGIAR crop varietal technologies into the United States. See, also Alston et al. (2020).

${ }^{16}$ With reference to using the IRR as a summary returns-to-research measure, Griliches (1958, p. 425) wrote "My objection to this procedure is that it values a dollar spent in 1910 at $\$ 2,300$ in 1933 . This does not seem very sensible to me. I prefer to value a 1910 dollar at a reasonable rate of return on some alternative social investment."
} 
76\% (986 estimates) report IRRs, while 312 report benefit-cost ratios (BCRs) (Table 3, upper half). Given the wide dispersion and positive skewness in the distribution of the reported rates of return, the median is a more informative measure of the central tendency than the mean. The median of the reported IRRs for U.S. agricultural R\&D is $31.9 \%$ per year and the median of the reported BCRs is 12.0 , roughly in line with the corresponding medians for the reported rest-ofworld evidence. ${ }^{17}$

\section{[Table 3: Returns to Agricultural $R \& D$ ]}

Although the IRR is merely a breakeven interest rate, equating the present values of costs and benefits, many policymakers (and even some economists!) treat IRRs as compounding rates of interest, analogous and comparable to the returns reported for financial products (e.g., mortgages, mutual funds and certificates of deposit). However, Hurley et al. (2014) showed that such an annualized percentage rate of return interpretation is generally incorrect and often leads to incredible implications. ${ }^{18}$ They also pointed out how the modified internal rate of return, MIRR (Lin 1976), offers an alternative to the IRR that can be reasonably interpreted as an annual percentage rate of return.

Hurley et al. (2014 and 2017) provide a detailed account of the properties of MIRRs, and the implicit, often undesirable assumptions (not least in the returns-to-research context) made in the calculation of IRRs. One of the desirable properties of an MIRR is its one-to-one

\footnotetext{
${ }^{17}$ However, such direct comparisons of broad aggregates are of limited value given differences in the nature of the evidence across countries and over time in terms of what commodities and types of research are being evaluated, and the details of the evaluation methods themselves (Rao et al. 2019a).

${ }^{18}$ As Alston et al. (2011, pp. 1271-2) showed, “... if the roughly $\$ 4$ billion invested in public agricultural R\&D in 2005 earned a return of $50 \%$ per annum compounding over 35 years, by 2040 the accumulated benefits would be worth $\$ 5,824,000$ billion (2000 prices) - more than 100 times the projected U.S. GDP in 2040 and more than 10 times the projected global GDP in 2040."
} 
correspondence with a BCR if a common discount rate and research timeline are used to calculate the rates of return for different projects. Using the BCR-IRR relationship elucidated by Hurley et al. (2014), Rao et al. (2019b) developed and deployed a procedure to recalibrate the reported IRRs into a standardized set of imputed BCRs and MIRRs, where the discount rates and research timelines are held constant, thus improving comparability among the estimates. The bottom half of Table 3 presents these imputed BCRs and MIRRs for the United States and the rest-of-the world using a common discount rate of 5\% and a research evaluation timeline (from the initiation of costs to the cessation of benefits) of 30 years, roughly the average timeline of the reported evidence. These results indicate a median BCR of 7.5 for investments in U.S. agricultural $\mathrm{R} \& \mathrm{D}$, corresponding to a MIRR of $12.3 \%$ per year. The comparable median rest-ofworld estimates are a BCR of 9.0 and a MIRR of $13.0 \%$ per year. These estimates are indicative of a sustained and substantial underinvestment in agricultural science both in the United States and globally. In spite of this government failure on top of market failure, innovation in American agriculture has accomplished a great deal and has contributed positively to global agricultural growth and change.

\section{Clusters of Innovation in American Agriculture}

Pardey and Alston (2019) discuss and document a century of transformative change in U.S. agriculture (1910-2007) in which they pay particular attention to the potential sources of a mid-century (1950s-1980s) surge and subsequent slowdown in farm productivity growth. They liken this farm productivity pattern to the earlier surge and slowdown in the broader economy identified by Gordon $(2000,2016)$, which he associated with great "clusters of inventions." 19

\footnotetext{
${ }^{19}$ Rasmussen (1962) had a similar notion of technological clusters or sequential technological revolutions driving the arc of history regarding U.S. agriculture, noting that up to the time of his writing: "Two revolutions in American
} 
Borrowing those ideas and in a similar spirit, Pardey and Alston (2019) suggest that much of the past time path of U.S. agricultural input use, production, productivity, and prices can be understood in terms of clusters of agricultural inventions and the structural changes in the farm economy they enabled, including (1) "mechanical” (mostly labor-saving) technologies; (2) improved animal breeds and crop varieties and other "biological" innovations; (3) synthetic fertilizers, pesticides, and other "chemical" technologies; and (4) more recently, "information" technologies; all employed in conjunction with ever-evolving knowledge and improved understanding of and changes in agricultural production and practices. This section builds on the discussion of innovation clusters by Pardey and Alston (2019) paying greater attention to the more-recent period while placing the newer innovations in a longer-run historical context.

Mechanization played a large early role in the $20^{\text {th }}$ Century transformation of U.S. agriculture. As well as much human labor, machines saved considerable amounts of land from having to be used to produce feed for horses and mules, and facilitated the consolidation of farms into many fewer and larger units. The tractor, in particular, saved millions of acres of land and the work of many men and women. In 1910, the United States had a total of 6.4 million farmers, farming 881 million acres using a total of 24 million horses and mules and just 1,000 tractors. After its peak in 1917 at 27 million animals, the stock of work horses and mules on U.S. farms dropped eventually to a low of 1.4 million in 1974 (Figure 7). Meanwhile, from just 50,000 tractors in 1917, the total grew to 4.5 million tractors in 1957.

agriculture reflect the impact of technological change on farming during the past century. The first revolution saw the change from manpower to animal power, and centered about the Civil War. The second revolution saw the change from animal power to mechanical power and the adaptation of chemistry to agricultural production. It centered around the post-World War II period. The transition from animal power to mechanical power is virtually complete (Rasmussen, 1962, p. 578).” 
[Figure 7: American Agricultural Mechanization, 1867-2012]

Along with tractors, farmers also adopted automobiles and motor trucks that were not developed specifically or exclusively for agriculture, as well as other machines that were useful only in agriculture, such as reapers, mowers, binders, and combines (Figure 8, Panel a). To a great extent this was a private-sector process, in which many of the innovations were patented technologies embodied in tractors and related machines produced privately and sold to farmers. Public agricultural (and other) R\&D was complementary but played a minor role here compared with its role in other types of innovations such as new crop varieties, and farming systems.

[Figure 8: Adoption Paths for Selected Major U.S. Farming Innovations, 1920-2018]

As can be seen in Panel a of Figure 8, biological innovations, in particular improved crop varieties that were responsive to chemical fertilizers, took center stage a little later-although they were clearly part of the story all along (Olmstead and Rhode 2008). For example, hybrid corn varieties were adopted rapidly in Iowa in the early 1930s, but it took until the 1960s for vastly improved hybrids to achieve 100 percent adoption throughout the United States (Griliches 1957, Dixon 1980, Hallauer and Miranda 1981). Varietal improvement has continued for corn and other crops, including food crops such as wheat and rice for which public investments have been more important. These innovations, with others, laid the foundation for genetically engineered (GE) hybrid corn varieties to be developed and adopted, beginning in 1996 (Fernandez-Cornejo et al. 2014). Similar, though typically less dramatic genetic innovations were common to many agricultural crop and livestock species, and contributed to the rapid rise of yields and aggregate productivity during the second half of the $20^{\text {th }}$ century (Olmstead and Rhode 2008). 
Chemical technologies for agriculture assumed importance beginning in the 1960s. The early 20th century invention of the Haber-Bosch process for the economical manufacturing of synthetic nitrogen fertilizer in particular was profoundly important for enhanced crop yields, especially when combined with complementary genetics and crop management practices. The U.S. on-farm adoption process for these fertilizers and associated varieties was notable in the 1960s and 1970s. Partly as a post-war dividend, synthetic pesticide technologies took off around the same time, soon to become subject to environmental regulation following the publication of Rachel Carson's "Silent Spring” in 1962. A great many forms of agricultural chemical technologies have been developed, registered and approved for commercial use, and adopted by farmers (and in many cases subsequently deregistered or heavily regulated and disadopted) including fertilizers, growth promotants, herbicides, fungicides, insecticides, antibiotics and other veterinary medicines.

More recently, genetically engineered (GE) crop varieties have been developed that could serve as better complements to or substitutes for these chemical technologies. Predominant among these are herbicide tolerant (HT) varieties of cotton, corn, soybeans, and canola, which permit herbicides to replace mechanical tillage for weed control, and pesticide inherent (PI) varieties (e.g, Bt cotton and corn) that reduce (or eliminate) the requirement for chemical pesticides for controlling specific pests. These technologies tend to predominate where they are available for adoption and confer significant benefits to farmers, consumers, and technology firms (see, e.g., Fernandez-Cornejo et al. 2014; Qaim 2016). Furthermore, HT technologies are complementary to conservation tillage practices (Perry et al. 2016), such that minimum-till and no-till systems are now used on a majority of acres of U.S. wheat (67\% in 2017), corn (65\%, 2016), and soybeans $(70 \%, 2012)$ (Classen et al. 2018). Conservation tillage practices reap their 
own rewards in terms of reduced soil compaction, improved water infiltration (and so reduced runoff), promotion of soil fauna and biological processes, and increased soil organic matter, most of which have beneficial agricultural production and environmental outcomes. ${ }^{20}$

To date, however, GE varieties have been developed and adopted widely for only a few crops (in particular soybeans, cotton, corn, canola, and papaya) and only in a few countries (Qaim 2016). This reflects a combination of regulatory and market resistance, which has discouraged the development of technologies for these and other applications in the countries that are open to GE technologies; more so in those that are opposed. The United States is predominant both as a developer and adopter, but even in the United States the regulatory barriers are substantial, adding years of delay and hundreds of millions of dollars in costs (see, e.g., Kalaitzandonakes et al. 2006). ${ }^{21}$ Panel b of Figure 8 displays the U.S. adoption paths for GE varieties of corn and soybeans on an expanded shorter time scale, where they can be juxtaposed with adoption paths for digital (and related information) technologies used in U.S. crop production in the modern era. This Panel captures key elements of the current innovative landscape for agriculture, emphasizing genetic innovation and other data-intensive technologies. Digital farming technologies (including "precision agriculture" or "variable rate" technologies), which help farmers gather information and adjust production practices according

\footnotetext{
${ }^{20}$ Changes in the emphasis of agricultural innovation might have changed the requirements for maintenance research as a share of total research, since the Red Queen effect applies particularly to genetic and chemical pestand disease-management technologies, less so to mechanical or digital innovations. This might help account for the mid-2 $0^{\text {th }}$-century surge (associated with adoption of mechanical innovations) in U.S. farm productivity and the subsequent slowdown (during the decades emphasizing chemical and biological innovation). In this respect, digital technologies may be more like mechanical technologies, although rapid (planned) obsolescence is a predominant feature in much digital technology.

${ }^{21}$ Compared with the earlier path for hybrid corn, these ones are shorter reflecting the advantages of modern science and communications technologies, but once we allow for an additional decade of regulatory lags, the overall postresearch development and adoption process is still on the order of 20 years for these technologies - like hybrid corn within Iowa, six decades previously.
} 
to changes in field conditions over space and time, are beginning to gain ground in U.S. farm production. Major examples include GPS (global positioning system)-based remote-sensing and guidance systems, soil and yield mapping based on GPS (perhaps in conjunction with satellite and aerial photography), and variable-rate technology (VRT) (Lowenberg-DeBoer and Erickson 2019; Jia et al. 2019).

Field operators can use GPS guidance systems to auto-steer tractors, combines, and other machines, which helps pinpoint precise field locations and reduce operator fatigue (Schimmelpfennig 2016). Precision technologies can also help farm operators map their fields better. Yield monitors mounted on harvesters can be used to record data on yields with GPS coordinates that the operator can use to monitor changes in crop yield across the field and from year to year. These data can be combined with data from soil maps using related technologybased on core samples or soil sensors that use electrical conductivity to test soil— understand the sources of yield variation and act on the information. Lastly, variable-rate technology (VRT) allows farmers to customize the application of irrigation water, fertilizer, chemicals, and pesticides spatially and over time using data from remote sensors or GPS dataoften from yield and soil maps or guidance systems. Farmers can even use VRT to plant different types of seeds or to apply different agricultural chemicals at different rates at different locations with a single pass of the tractor. And, looking forward, these technologies will be used to allow precise mechanical or chemical weeding and cultivation around individual plants, among other things.

Panel $b$ of Figure 8 includes adoption curves for six types of technology in this context, as well as two types of GE crops (corn and soybeans). The plots for the GE crops start earlier, and rise more rapidly. By 2006, only 10 years after initial release, GE varieties had already been 
adopted on 60 percent of corn and 90 percent of soybean acres. In contrast, the adoption curves for most of the digital and related precision farming technologies are much flatter. Autosteer technology, which was first introduced around the same time as the GE crop varieties was used on 60 percent of acres in 2015, while the other digital technologies were less widely adopted.

As discussed by Schimmelpfennig (2016), some of these technologies are simple to adopt and easy to use while others may come at a relatively high cost in terms of requiring specialized equipment or specific skills. These factors, along with functionality, have contributed to the differences observed in the rate of development and adoption of these technologies. Many of these tools are knowledge-and skill-intensive, and their profitable use requires location-, application-, and site-specific adaptation, all of which takes time to work out. Primarily, their limited use to date reflects the fact that it is still early days for many of these technologies in terms of matching data to models and real-time processing of very large data sets, engineering the machinery to go with the data and knowledge, and software development. The technologies themselves have been changing rapidly and the prospects are very bright.

In some cases we can understand the differences in adoption rates in terms of the nature of the technology as it relates to the factors mentioned by Schimmelpfennig (2016). For example, adoption of GE seeds did not require any significant investment in new knowledge (rather in some ways the technology replaced a requirement for knowledge about pest management with pest-management inherent seeds), and nor did it require any new equipment or new business relationships; it was a routine transition in an environment where farmers were used to adopting new hybrids reasonably often. The benefits were reasonably clear, the costs of change were small, and the benefit-cost calculus was straightforward—facilitated by much opportunity to begin small and observe neighbors and learn from their experience. However, the 
subsequent (implied) transition from conventional cropping to lo-till and no-till enabled by GE varieties took considerably longer because it required sometimes considerable own-farm-specific learning by doing about what works and what does not, which can be a time-intensive process.

Likewise, autosteer is a relatively simple technology and easy to learn to use (like GE seed it replaces a more difficult technology with a simpler one), and the benefit-cost calculus is reasonably straightforward. However, the same is not true for many other digital technologies. Some may require a very significant up-front investment in physical capital and acquisition of technical know-how (and thus implying large economies of size) to make use of a technology for which the benefits might be quite uncertain or where the landscape is changing rapidly such that even better options may become available soon. It is also pertinent to note that in 2017 the average age of farmers was 57.5 years (USDA-NASS 2019), other things equal older farmers are less likely to adopt innovations generally (Feder and Umali 1993) and perhaps more-so digital versus more traditional technologies with which they may be more comfortable.

Schimmelpfennig and Ebel (2016, p. 97) propose an additional possible explanation for sluggish adoption, if potentially complementary technologies are adopted and worked into production practices sequentially: "The one-technology-at-a-time approach to adoption may seem inefficient and time-consuming compared to adoption of complete, possibly complementary, packages of technologies, but this scheme has been shown to occur in other settings." If one part of the package is seen as costly or risky to adopt, this might have implications for the rates of adoption of other elements that are less useful alone.

In addition to these types of technologies, which are most visibly apparent in the context of major field crops, other types of digital technologies are being developed and used in the context of specialty crops or livestock production, as well as field crops. For example, in crop 
production, automated irrigation systems based on sensors that measure precipitation, evapotranspiration, and soil moisture in the root zone are used to improve the efficiency of water use and save labor; these are in their early stages of adoption. USDA, ERS (2020) report that “... fewer than 10 percent of irrigators make use of soil- or plant-moisture sensing devices or commercial irrigation scheduling services [and less than] 2 percent make use of computer-based simulation models to determine irrigation requirements based on consumptive-use needs by crop-growth stage under local weather conditions."

Autonomous or articulated weeding machines are under development, and some are already being used in farmers' fields (see, e.g., BlueRiver 2020). These include machines that can selectively spray or physically cut out weeds based on GPS references or computer vision (or image identification) technologies, thereby saving labor and reducing the environmental burden of herbicide (see, e.g., Fennimore and Cutulle, 2019; Filmer 2019). Drones and other selfdriving machines fitted with cameras, sniffers and other types of sensors are being developed and deployed to monitor the crop for drought and other stresses and check for pests and diseases. Analogous sensing technologies are being developed for monitoring soil nutrient (see, e.g., Teralytic 2020) and health status, including soil microbiome activity. Robotic and other devices fitted with sensors are also being developed and deployed to selectively harvest crops (e.g., apples, strawberries) with variable maturation dates.

In livestock production, digital technologies are already widely used and their use is progressing: for example, companies such as Lely (2020) have already commercialized robotic milking machines and digital cow tag systems that can be used to monitor and help manage 
animal health and feeding status for dairy cows..$^{22}$ As with crop production, "smart" livestock production technologies involve precision technologies and variable rate technologies, where the unit of observation now becomes the individual animal. Using modern information technology, farmers now can monitor and record details on numerous attributes of each animal, including its health status, its consumption of feed and other inputs, its productivity and reproductive performance. These data can be collected, and interpreted using machine learning and other processes in ways that make the information economically useful and permit better livestock management and more profitable decisions both with respect to individual animals and the entire herd or flock. Decisions regarding optimal culling age and feeding regimes can now be individualized based on individualized performance measures such as fertility, yield of meat (or milk), quality of meat (or milk), feed-conversion efficiency, and their implications for profitability. Some other precision livestock technologies serve to save labor and perform tasks more precisely, such as robotic milkers and automated feeders, and climate control technologies for housed livestock.

Growing from "just" $\$ 2.6$ billion in 2012 new agrifood startup companies attracted $\$ 16.6$ billion of investments worldwide in 2018 (AgFunder 2018, p. 15). ${ }^{23}$ The United States accounted for $\$ 7.9$ billion (48\%) of the total, China $\$ 3.5$ billion (21\%), and India $\$ 2.4$ billion (14\%). Startups based in California accounted for almost one-third of global investment and

\footnotetext{
${ }^{22}$ For example, an active smart ear tag can get data from individual animals such as temperature and activity patterns, which can be utilized in identification of illness, heat stress, estrous, and so on, and enable livestock producers to identify sick animals sooner and more accurately. This early detection leads to reduction in costs by lowering re-treatment rate and death loss, and getting animals back to peak performance faster.

${ }^{23}$ Other studies, such as Graff et al. (2020) and others, provide alternative quantification and discussion of venture capital investments in (R\&D intensive) agriculture startups, developed for different purposes. Not all the venture capital being invested in these (technology-oriented) companies is necessarily directed to activities that are consistent with R\&D measures reported in this chapter. Some of the funds are also invested in market development, promotion and related business activities such that only some (and often an unknown) fraction of the venture capital total is spent on R\&D per se.
} 
two-thirds of all U.S. investment; $92 \%$ of the U.S. total if funding to firms located in Massachusetts, New York, North Carolina, Colorado and Minnesota are also included. Investments in startups closer to the farmer-spanning areas such as soil testing, pest detection, precision agriculture, digital agricultural management, agronomic data, and predictive analytics - totaled $\$ 6.9$ billion ( $41.5 \%$ of the global total), with firms focused on the off- (or vertical-) farm segments - including food processing and production companies (such as Impossible Foods, Zymergen and Bowery Farming Inc.) and, especially, food delivery companies (such as Instacart and DoorDash) attracting \$10 billion in risk capital.

\section{The Next Wave of Agricultural Innovation: Ripple or Tsunami?}

Looking forward, we can see great potential for new product and process innovations-in particular digital and other data- and knowledge-intensive technologies, including genetic innovations - that will enable more and better food, fiber, and industrial raw materials to be produced on farms at much lower cost and with a smaller environmental footprint, worldwide. Realizing this potential will matter for the future trajectory of global public goods including climate change, other natural resource stocks, the world food equation, poverty and related civil or military strife. The extent to which these opportunities will be captured, and when, will be determined to a great extent by forces outside agriculture and outside the R\&D and technology sector. These forces will determine the availability and direction of resources available for public-sector agricultural $\mathrm{R} \& \mathrm{D}$, the regulations and rules governing the development, deployment, and adoption of new farm and food technologies, and the demand for products depending on the technologies used to produce them. 


\section{Induced Innovation}

As noted above, agriculture is unusual in that it faces knowledge depreciation arising from climate change and, in particular, the coevolution of pests and diseases. This gives rise to a demand for maintenance R\&D—simply to preserve past productivity gains. Much of the past work on crop varietal innovations can be seen in this light. The demand for innovation on farms is also driven by changing factor supply conditions, evolving demand for farm products (now including feedstock for biofuels and other industrial raw materials as well as traditional feed, food and fiber), and the peculiar regulatory environment for agriculture related to issues including varietal technologies, animal welfare in livestock production, and landscape amenities (and dis-amenities) from agricultural production. Farmers also face a changing market environment with demands for food products and food production processes mediated through private standards and mass media messages.

Over the long history, a major element of change was labor-saving innovation induced by farm labor scarcity. Past labor savings notwithstanding, reliable and timely availability of suitably skilled labor is a major concern of farmers today—especially in California's labor demanding specialty crops — and they are actively seeking technological alternatives for harvesting, weeding, irrigating, and a host of other farm operations as well as post-farm packing and handling. ${ }^{24}$ Farmers are also increasingly concerned over the reliability of natural rainfall and irrigation water, with variability and uncertainty in these dimensions exacerbated by climate change. Drought- and heat-tolerant varieties are being developed to mitigate these consequences

\footnotetext{
${ }^{24}$ Today's farm labor environment with its implications for the demand for labor-saving innovations is reminiscent of the period when the Bracero Program was terminated in 1964, stimulating the rapid deployment and adoption of the mechanical tomato harvester. Olmstead and Martin (1985) analyze the resulting controversy.
} 
(see, e.g., Cooper et al. 2014 and McFadden et al. 2019 in the case of drought-tolerant corn).

Information technologies combined with more precise and selective water delivery systems can reduce total water usage and vulnerability to drought.

Changing technological regulations generate a demand for replacement technologies. In recent years significant agricultural pesticides have been banned in some jurisdictions and are threatened in others owing to concern about their risks to the environment or human health. ${ }^{25}$ These include soil fumigants (e.g., methyl bromide), insecticides (e.g., neonicotinoids) and herbicides (e.g., glypohosate aka Roundup $\left.{ }^{\circledR}\right)$. When significant pesticides are deregistered, farmers demand new solutions. In some cases, the alternative to a banned chemical is another chemical or new genetics, but sometimes it simply means technological regression. For example, Roundup-resistant ${ }^{\circledR}$ varieties of corn, soybeans, and canola, combined with the herbicide glyphosate, permitted the widespread adoption of lo-till or no-till production systems that resulted in significant improvements in soil structure and reduced greenhouse gas emissions. If glyphosate were to be banned in the United States and Canada - as it has been (either totally or for selected uses) in some other countries recently—we could expect to see a reversion to older production systems using mechanical tillage for weed control and environmentally less benign herbicides. The pressure will be on to come up with an alternative to glyphosate that will be as effective for farmers and more acceptable to the regulators. This is a serious challenge.

Agriculture has generated various other environmental concerns related to air pollution (including greenhouse gases, particulate matter, and odors from livestock production) and water

\footnotetext{
25 Donley (2019, p. 1) reports: "There are 72, 17, and 11 pesticides approved for outdoor agricultural applications in the USA that are banned or in the process of complete phase out in the EU, Brazil, and China, respectively. Of the pesticides used in USA agriculture in 2016, 322 million pounds were of pesticides banned in the EU, 26 million pounds were of pesticides banned in Brazil and 40 million pounds were of pesticides banned in China. Pesticides banned in the EU account for more than a quarter of all agricultural pesticide use in the USA."
} 
pollution (including nitrates in groundwater and surface water giving rise to human health and environmental issues). With increasing awareness of these issues, and the likelihood of government intervention in one form or another, demand is growing for alternative technologies that will enable more precise use of inputs and better control of unwanted outputs. Likewise, whether motivated by animal welfare concerns or other issues, new regulations over livestock production practices — such as castration; dehorning; pens for calves, sows, and egg-laying hens; use of antibiotics and other veterinary medicines - give rise to demand for new technologies.

In many instances, genetic innovations offer promising solutions to the problems created by the changing regulatory environment. However, genetic technologies also are subject to considerable regulatory weight. The science of genetic innovation has improved by leaps and bounds over recent decades, but society has placed arbitrary strictures (unsupported by scientific evidence) over some of the most powerful tools in the tool-kit available to the modern-day geneticist. In the United States, genetically engineered crop varieties are subject to much greater regulatory control than their conventionally bred counterparts, even though they pose no greater risk to human health or the environment (see, e.g., Qaim 2018). In many other countries, GE crops are effectively banned. More recent innovations, such as gene-editing techniques, promise much greater possibilities for targeted genetic changes in commercial species, but they too might face serious regulatory barriers that could stifle that potential. ${ }^{26}$ Some countries have already opted to treat gene-edited varieties as GMOs, subject to severe restrictions (see, e.g., Wight

\footnotetext{
${ }^{26}$ Van Eenennaam (2019) provides a review of the gene-editing targets for cattle, while Baltes et al. (2017) provide an overview of the gene editing opportunities and technical challenges for plant transformations. Qaim (2020) discusses the risk of over-regulation of new plant breeding technologies (NPBTs). He suggests: "While the science is exciting and some clear benefits are already observable, overregulation and public misperceptions may obstruct efficient development and use of NPBTs. Overregulation is particularly observed in Europe, but also affects developing countries in Africa and Asia, which could benefit the most from NPBTs" (Qaim 2020, p.1)
} 
2018, regarding the European Court of Justice ruling regarding the use of gene editing in the $\mathrm{EU})$.

It is not easy to get a good handle on the innovations in the pipeline or on the drawing board, especially since so much of what is going on is being undertaken privately, and in private - in particular when we talk about digital agriculture but also for some aspects of genetic innovations. ${ }^{27}$ As we have discussed, genetic innovation in plants and animals includes the results from conventional breeding (albeit supported by the tools of modern biotechnology such as marker-assisted breeding), genetic engineering, and gene-editing. Much of the emphasis of this work tends to be focused on the main agricultural species and the main production systems, for sound economic reasons. Apart from yield potential, tolerance of abiotic stresses (drought, frost, and heat), and resistance to pests and diseases, crop geneticists are looking for various other agronomic advantages and product quality attributes. In the case of apples and table grapes, for example, fruit quality attributes are an important focus of private and public breeding efforts and varieties in use are changing rapidly. ${ }^{28}$

As noted, digital farming innovations (including precision technologies and variable rate technologies) have the potential to save (and also reduce dependence on uncertain supplies of) labor and irrigation water; they also have the potential to save on materials and reduce environmental spillovers associated with fertilizers and pesticides (see, e.g., Schimmelpfennig 2018). Some of these technologies also have the potential to reduce the requirement for farm labor to perform dangerous and arduous tasks that can be done better by machines. Some of

\footnotetext{
${ }^{27}$ The public sector also is active in these areas and public-sector science is less secretive.

${ }^{28}$ Alston and Sambucci (2019) discuss and document the rapid rate of innovation in table grape varieties in California, reflecting both public and increasingly private innovative activity. A total of 85 varieties are currently in production, and the mixture in vineyards is changing.
} 
these prospects will be enhanced by government policies and the political action of various interest groups, including the woke food policy movement, and others will be hampered. Issues have begun to arise over the IP rights to the data generated by farmers about their business, using machines embodying technology owned by others (AFBF 2018; Janzen 2019). A related issue is the changing scope for farmers as "tinkerers" to economically modify increasingly complex and sophisticated technologies. There can be no doubt farmers will be continue to be busy tinkering, modifying machines and using them in ways that were not imagined by the engineers that built them in the first instance, but it seems likely that an increasing share of the total innovation in American agriculture will be based on patented technologies developed in the per profit sector, continuing recent trends — whether we are talking about mechanical, genetic, chemical or digital technologies.

\section{Policy Perspectives}

Government policy has been a central theme in our discussion of agricultural innovation because the government plays a central role both in contributing directly to the innovation process, as a major provider of agricultural $R \& D$, and in setting the rules of the game that determine the supply of and demand for agricultural innovations. In the current environment for agriculture, demands for private innovation investments are being influenced by government through the prospect of new regulations (or taxes) applied to agricultural production, including

technological regulations and environmental regulations to reduce greenhouse gas emissions and other spillovers from agriculture; and through the influence of policy on the supply of inputs (especially labor and water) to agriculture, and on the markets for farm products. A more subtle influence of government is through changing support for public sector R\&D (in terms of both the total investment and the balance of investments) influenced by a changing role of scientific 
evidence in policy and shifting public preferences. ${ }^{29}$ These shifts create some opportunities for the private sector and foreclose others.

The National Academies of Science, Engineering and Medicine (2019) recently published a new agricultural research agenda for the United States entitled Science Breakthroughs to Advance Food and Agricultural Research by 2030. This report identifies innovative, emerging scientific advances for making the U.S. agricultural and food system more efficient, resilient, and sustainable. The report presents five priorities:

1. Increasing understanding of the animal, soil, and plant microbiomes and their broader applications across the food system.

2. Harnessing the potential of genomics and precision breeding to improve plant and animal traits.

3. Capitalizing on agri-food informatics to enable advanced analytics using data sciences, information technology, and artificial intelligence

4. Employing existing sensors and developing new sensing technologies to enable rapid detection and monitoring

5. Prioritizing transdisciplinary science and systems approaches.

A fundamental motivation for this effort was a concern over the shrinking total support for public agricultural R\&D in the United States and the loss of direction in terms of the focus of the shrinking public funds. Among these five priorities, most of the topics entail significant opportunities for private entrepreneurial activity to generate proprietary research products. Notably, three of the five are predominantly digital, data-intensive systems.

\footnotetext{
${ }^{29}$ For example, Pardey et al. (2013) show that the share of SAES (state agricultural experiment station) research oriented to farm productivity fell steadily from $69 \%$ in 1985 to $56 \%$ in 2009 .
} 


\section{Conclusion}

U.S. agriculture was transformed during the 20th century by waves of innovation with mechanical, biological, chemical, and information technologies. Compared with a few decades ago, today's agriculture is much less labor intensive and farms are much larger and more specialized, supplying a much-evolved market for farm products. Over recent decades, the

global landscape for agricultural R\&D has shifted away from farms, away from the public sector towards the private sector, and away from the United States towards agriculturally important middle-income countries, especially China, India and Brazil. Investments are stalling even though meta-evidence shows that past U.S. investments in R\&D have yielded very favorable returns: median reported benefit cost-ratios in the range of 12:1. Sustained U.S. investment and innovation will be required to preserve past productivity gains in the face of climate change, coevolving pests and diseases, and changing technological regulations - let alone increase productivity. Great potential exists for innovation in crop and livestock genetics and digital farming technologies to generate new products and production processes, but innovators have to overcome increasingly strong headwinds from social and political forces that seek to dictate technology choices. 


\section{References}

Adusei, E.O. and G.W. Norton, "The Magnitude of Agricultural Maintenance Research in the USA," Journal of Production Agriculture 3 (1990): 1-6.

AFBF (American Farm Bureau Federation). "Privacy and Security Principles for Farm Data," 2016. Available on line at www.fb.org/issues/technology/data-privacy/privacy-andsecurity-principles-for-farm-data.

AgFunder. AgriFood Tech Investing Report 18-Year in Review, 2018. Available at https://agfunder.com/research/agrifood-tech-investing-report-2018/.

Alston, J.M. "Spillovers.” Australian Journal of Agricultural and Resource Economics 46(3)(September 2002): 315-346.

Alston, J.M. "Reflections on Agricultural R\&D, Productivity, and the Data Constraint: Unfinished Business, Unsettled Issues." American Journal of Agricultural Economics 100(2)(2018): 392-413. doi:10.1093/ajae/aax094

Alston, J.M. "Woke Farm and Food Policies in the Post-Truth Era: Calamitous Consequences for People and the Planet." Unpublished paper prepared for the Festshrift conference in honor of Gordon Rausser. University of California, Davis, October 2019.

Alston, J.M., M.A. Andersen, J.S. James and P.G. Pardey. "The Economic Returns to U.S. Public Agricultural Research.” American Journal of Agricultural Economics 93(5)(2011): $1257-1277$.

Alston, J.M., M.A. Andersen, J.S. James and P.G. Pardey. Persistence Pays: U.S. Agricultural Productivity Growth and the Benefits from Public R\&D Spending. New York: Springer, 2010.

Alston, J.M., S. Dehmer and P.G. Pardey. "International Initiatives in Agricultural R\&D: The Changing Fortunes of the CGIAR.” Chapter 12 in P.G. Pardey, J.M. Alston and R.R. Piggott, eds. Agricultural R\&D in the Developing World: Too Little, Too Late?

Washington, DC: International Food Policy Research Institute, 2006.

Alston, J.M. and P.G. Pardey. "Agriculture in the Global Economy.” Journal of Economic Perspectives 28,1(2014): 121-146.

Alston, J.M. and P.G. Pardey. "Transforming Traditional Agriculture Redux." Chapter in C. Monga and J. Lin, eds. The Oxford Handbook of Structural Transformation. Oxford: Oxford University Press, 2019.

Alston, J.M., P.G. Pardey and X. Rao. The Payoff to Investing in CGIAR Research. Research Report. Washington DC: SoAR Foundation, 2020 (forthcoming).

Alston, J.M. and O. Sambucci. "Grapes in the World Economy." Chapter 1 of Dario Cantu and Andrew M. Walker, eds, The Grape Genome, for the Springer Publishers Compendium of Plant Genomes, 2019.

Andersen, M.A., J.M. Alston, P.G. Pardey, and A. Smith. "A Century of U.S. Farm Productivity Growth: A Surge Then a Slowdown." American Journal of Agricultural Economics 100(4)(2018): 1072-90. doi.org/10.1093/ajae/aay023 
Baltes, N.J., J. Gil-Humanes and D.F. Voytas. "Genome Engineering and Agriculture: Opportunities and Challenges." Chapter 1 in D.P Weeks and B. Yang eds. Gene Editing in Plants. Progress in Molecular Biology and Translational Science, Volume 149 Amsterdam: Elsevier, 2017. Available at https://www.sciencedirect.com/bookseries/progress-inmolecular-biology-and-translational-science

BlueRiver Technology. "Our See and Spray Machines,” 2020. Available at http://smartmachines.bluerivertechnology.com/.

Bureau of Economic Analysis (BEA). National Income and Product Accounts Tables. Table 1.3.5. Gross Value Added by Sector. Downloaded February 14, 2017. https://www.bea.gov/iTable/iTable.cfm?ReqID=9\&step=1\#reqid=9\&step=3\&isuri=1\&904 $=1929 \& 903=24 \& 906=\mathrm{a} \& 905=1000 \& 910=\mathrm{x} \& 911=0$

Carson, R. Silent Spring. Boston: Houghton Mifflin, 1962.

Chai, Y, P.G. Pardey, C. Chan-Kang, J. Huang, K. Lee and W. Dong. "Passing the Food and Agricultural R\&D Buck? The United States and China." Food Policy 86 (2019) doi.org/10.1016/j.foodpol.2019.101729.

Claassen, R., M. Bowman, J. McFadden, D. Smith and S. Wallande. Tillage Intensity and Conservation Cropping in the United States, EIB-197, U.S. Department of Agriculture, Economic Research Service, 2018.

Clancy, M., P. Heisey, Y. Ji, G. Moschini. "The Roots of Agricultural Innovation: Patent Evidence of Knowledge Spillovers." Chapter in P. Moser, ed. Economics of Research and Innovation in Agriculture, NBER conference volume in process, March 12, 2020.

Coase, R.H. "The Nature of the Firm.” Economica 4(16)(1937): 386-405.

Cooper, M., C. Gho, R. Leafgren, T. Tang, and C. Messina. 2014. "Breeding Drought-Tolerant Maize Hybrids for the U.S. Corn Belt: Discovery to Product," Journal of Experimental Botany 65(21): 6191-204.

Dehmer, S.P., P.G. Pardey, J.M. Beddow and Y. Chai. "Reshuffling the Global R\&D Deck, 1980-2050.” PLOS ONE (March 2019): https://doi.org/10.1371/journal.pone.0213801.

Deloitte Centre for Health Solutions. "Measuring the Return on Pharmaceutical Innovation 2014: Turning a Corner?" Deloitte LLP (United Kingdom), 2014.

Dixon, R. Hybrid Corn Revisited.” Econometrica 48(6)(1980): 1451-61.

Donley, N. "The USA Lags Behind other Agricultural Nations in Banning Harmful Pesticides." Environmental Health 18(Article 44)(2019) 18:44 https://doi.org/10.1186/s12940-0190488-0.

Erickson, B., J. Lowenberg-DeBoer, and J. Bradford. 2017 Precision Agriculture Dealership Survey. Lafayette, Indiana: Departments of Agricultural Economics and Agronomy, Purdue University. December 2017.

Feder, G. and D.L. Umali. "The Adoption of Agricultural Innovations: A Review." Technological Forecasting and Social Change 43(1993): 215-239. 
Fennimore, S., and M. Cutulle. "Robotic Weeders Can Improve Weed Control Options for Specialty Crops." Pest Management Science 75(7)(2019): 1767-1774.

https://doi.org/10.1002/ps.5337

Fernandez-Cornejo, J., S. Wechsler, M. Livingston and L. Mitchell Genetically Engineered Crops in the United States. USDA Economic Research Report No. 162. Washington, D.C.: United States Department of Agriculture, 2014.

Filmer, A. "Automated Weeders are Attracting More Interest: Steve Fennimore Explains." Farms.Com News September 26, 2019. www.farms.com/news/automated-weeders-areattracting-more-interest-steve-fennimore-explains-149734.aspx

Fuglie, K.O. and D. Schimmelpfennig, eds. Public-Private Collaboration in Agricultural Research: New Institutions and Economic Implications. Ames: Iowa State University Press, 2000.

Gelvin, S.B. "Agrobacterium-Mediated Plant Transformation: The Biology Behind the "GeneJockeying” Tool." Microbiology and Molecular Biology Reviews 67(1)(2003): 16-37. doi: 10.1128/MMBR.67.1.16-37.2003

Glover, M., M. Buxton, S. Guthrie, S. Hanney, A. Pollitt and J. Grant. "Estimating the Returns to UK Publicly Funded Cancer-related Research in Terms of the Net Value of Improved Health Outcomes." BMC Medicine 12, 99(2014). doi.org/10.1186/1741-7015-12-99.

Gordon, R.J. "Interpreting the 'One Big Wave' in U.S. Long-Term Productivity Growth.” NBER Working Paper 7752. Cambridge, MA: National Bureau of Economic Research, June 2000.

Gordon, R.J. The Rise and Fall of American Growth. Princeton: Princeton University Press, 2016.

Graff, G.D., F. de Figueiredo Silva, and D. Zilberman. "Venture Capital and the Transformation of Private R\&D for Agriculture." Chapter in P. Moser, ed. Economics of Research and Innovation in Agriculture, NBER conference volume in process, March 12, 2020.

Griliches, Z.: "Hybrid Corn: An Exploration in the Economics of Technological Change," Econometrica 25 (4)(1957): 501-522.

Griliches, Z. "The Sources of Measured Productivity Growth: United States Agriculture, 194060.” Journal of Political Economy 71(4)(1963): 331-346.

Hall, B.H., J. Mairesse and P. Mohnen. "Measuring the Returns to R\&D." chapter 24 in B. Hall and N. Rosenberg eds., Handbook of the Economics of Innovation, Volume 2. Amsterdam: Elsevier, 2010.

Hallauer, A.R. and J.B. Miranda. Quantitative Genetics in Maize Breeding. Ames: Iowa State University Press, 1981.

HERG (Health Economics Research Group), OHE (Office of Health Economics) and RAND Europe. Medical Research: What's it Worth? Estimating the Economic Benefits from Medical Research in the UK. London: UK Evaluation Forum, 2008. Available at www.mrc.ac.uk/publications/browse/medical-research-whats-it-worth/ 
Hurley, T.M, X. Rao and P.G. Pardey. "Re-examining the Reported Rates of Return to Food and Agricultural Research and Development." American Journal of Agricultural Economics 96(5)(2014):1492-1504.

Janzen, T. "Do Farmers Still Care About Ag Data Privacy?” Janzen Ag Law, 2019. Available at www.aglaw.us/janzenaglaw/2019/1/3/farmers-care-about-data.

Jia, X., A. Khandelwal1, D.J. Mulla, P.G. Pardey, V. Kumar. "Bringing Automated, RemoteSensed, Machine Learning Methods to Monitoring Crop Landscapes at Scale." Agricultural Economics 50 (S1)(2019): 41-50.

Johnston, L. and S.H. Williamson. What Was the U.S. GDP Then? MeasuringWorth. Downloaded January 2017 from https://www.measuringworth.com/datasets/usgdp/.

Joglekar, A.B., P.G. Pardey and U. Wood-Sichra. Where in the World are Crops Grown? HarvestChoice Brief. St. Paul, Minnesota and Washington, D.C.; University of Minnesota and International Food Policy Research Institute, 2016.

Jorgenson, D.W. and F.M. Gollop. "Productivity Growth in U.S. Agriculture: A Postwar Perspective." American Journal of Agricultural Economics 74 (3)(1992): 745-50.

Kalaitzandonakes, N., J.M. Alston, and K.J. Bradford. "Compliance Costs for Regulatory Approval of New Biotech Crops.” Chapter 3 of R.E. Just, J.M. Alston, and D. Zilberman (eds.) Regulating Agricultural Biotechnology: Economics and Policy. New York: SpringerVerlag, 2006.

Lee, K., P.G. Pardey, S. Miller and S. Dehmer. "An Examination of Private (Sectoral and FirmLevel) Investments in U.S. Food and Agricultural R\&D, 1950-2014.” InSTePP Working Paper. St. Paul; University of Minnesota, Department of Applied Economics, 2020 (in process).

Lely. "Milking: More Milk in the Tank with Less Effort," 2020. Available at https://www.lely.com/us/solutions/milking/

Lin, A.Y.S. "The Modified Internal Rate of Return and Investment Criterion." Engineering Economist 21 (4)(1976): 237-47.

Lin, J.Y. "Rural Reforms and Agricultural Growth in China." American Economic Review 82(1)(1992): 34-51

Lowenberg-DeBoer, J. and B. Erickson. "Setting the Record Straight on Precision Agriculture Adoption.” Agronomy Journal 111(2019):1-18. doi:10.2134/agronj2018.12.0779.

MacDonald, J.M., R.A. Hoppe and D. Newton. Three Decades of Consolidation in U.S. Agriculture, EIB-189, U.S. Department of Agriculture, Economic Research Service, March 2018.

McFadden, J., D. Smith, S. Wechsler and S. Wallander. Development, Adoption, and Management of Drought-Tolerant Corn in the United States, EIB-204, U.S. Department of Agriculture, Economic Research Service, 2019.

National Academies of Science, Engineering and Medicine. Science Breakthroughs to Advance Food and Agricultural Research by 2030. Washington DC, National Academies Press, 2019. 
National Science Board. Science and Engineering Indicators 2018. NSB-2018-1. Alexandria, VA: National Science Foundation. Available at https://www.nsf.gov/statistics/indicators/. 2018.

National Science Foundation (NSF), National Center for Science and Engineering Statistics. National Patterns of R\&D Resources (annual series). 2019. Downloaded from https://www.nsf.gov/statistics/2018/nsb20181/data/appendix on Dec 27th 2019.

OECD (Organisation for Economic Co-operation and Development), Frascati Manual 2015: Guidelines for Collecting and Reporting Data on Research and Experimental Development, The Measurement of Scientific, Technological and Innovation Activities. Paris: OECD Publishing, 2015.

Okrent, A.M., and J.M. Alston. Demand for Food in the United States: A Review of Literature, Evaluation of Previous Estimates and Presentation of New Estimates of Demand. Giannini Foundation Monograph Series No. 48, Giannini Foundation of Agricultural Economics, Berkeley, CA, 2011.

Okrent, A.M., and J.M. Alston. The Demand for Disaggregated Food-Away-from-Home and Food-at-Home Products in the United States. Economic Research Report no. 139, Washington, DC: U.S. Department of Agriculture - Economic Research Service, 2012.

Okrent, A.M., H. Elitzak, T. Park, and S. Rehkamp. Measuring the Value of the U.S. Food System: Revisions to the Food Expenditure Series, TB-1948, U.S. Department of Agriculture, Economic Research Service, 2018.

Olmstead, A.L. and P.L. Martin. "The Agricultural Mechanization Controversy." Science 227(4687)(1985): 601-606. doi:10.1126/science.227.4687.601

Olmstead, A.L. and P.W. Rhode. Creating Abundance: Biological Innovation and American Agricultural Development. Cambridge: Cambridge University Press, 2008.

Olmstead, A.L. and P.W. Rhode. "The Red Queen and the Hard Reds: Productivity Growth in American Wheat, 1800-1940.” Journal of Economic History 62 (4)(2002): 929-966.

Perry, E.D., G. Moschini and D.A. Hennessy. "Testing for Complementarity: Glyphosate Tolerant Soybeans and Conservation Tillage." American Journal of Agricultural Economics 98(3)(2016): 765-784. doi: 10.1093/ajae/aaw001

Pardey, P.G. and J.M. Alston. "Unpacking the Agricultural Black Box: The Rise and Fall of American Farm Productivity Growth.” InSTePP Working Paper. St. Paul; University of Minnesota, Department of Applied Economics, 2019 (in process).

Pardey, P.G., M.A. Andersen, B.J. Craig and A.K.A. Acquaye. "Primary Data Documentation: U.S. Agricultural Input, Output, and Productivity Series, 1949-2002, Version 4.” St. Paul: InSTePP, University of Minnesota, 2006. Available at https://www.instepp.umn.edu/products/instepp-primary-data-documentation-usagricultural-input-output-and-productivity-series.

Pardey, P.G., J.M. Alston and C. Chan-Kang. Public Food and Agricultural Research in the United States: The Rise and Decline of Public Investments, and Policies for Renewal. AGree Report. Washington D.C.: AGree, 2013 
Pardey, P.G., J.M. Alston and V.W. Ruttan. "The Economics of Innovation and Technical Change in Agriculture." Chapter 22 in B.H. Hall and N. Rosenberg, eds. Handbook of the Economics of Innovation, Amsterdam: Elsevier, 2010.

Pardey, P.G., J.M. Alston, J.E. Christian and S. Fan. Hidden Harvest: U.S. Benefits from International Research Aid, Food Policy Report, Washington, D.C.: International Food Policy Research Institute, September 1996.

Pardey, P.G., J.M. Alston, C. Chan-Kang, T.M. Hurley, R.S. Andrade, S.P. Dehmer, K. Lee, and X. Rao. "The Shifting Structure of Agricultural R\&D: Worldwide Investment Patterns and Payoffs." Chapter 1 in N. Kalaitzandonakes, E.G. Carayannis, E. Grigoroudis, and S. Rozakis, eds. From Agriscience to Agribusiness: Theories, Policies and Practices in Technology Transfer and Commercialization. Cham, Switzerland: Springer, 2018.

Pardey, P.G. and J.M. Beddow. Agricultural Innovation: The United States in a Changing Global Reality. CCGA Report. Chicago: Chicago Council on Global Affairs, 2013.

Pardey, P.G., C. Chan-Kang, J.M. Beddow and S.M. Dehmer. 2016. "InSTePP International Innovation Accounts: Research and Development Spending, Version 3.5 (Food and Agricultural R\&D Series)-Documentation." St. Paul, MN: International Science and Technology Practice and Policy (InSTePP). Available at www.instepp.umn.edu/sites/instepp.umn.edu/files/product/downloadable/InSTePP\%20Inter national\%20Innovation\%20Accounts-R\%26D\%20ver3.5\%282SEPT2016\%29.pdf.

Pardey, P.G., C. Chan-Kang, S.P Dehmer and J.M. Beddow. "Agricultural R\&D is on the Move." Nature 15(537)(2016): 301-303.

Pardey, P., B. Koo, J. Drew, J, Horwich and C. Nottenburg. "The Evolving Landscape of Plant Varietal Rights in the United States, 1930-2008." Nature Biotechnology 31(1)(2013): 2529.

Pardey, P.G., J. Roseboom and J.R. Anderson. "Regional Perspectives on National Agricultural Research." Chapter 7 in P.G. Pardey, J. Roseboom, and J.R. Anderson, eds. Agricultural Research Policy: International Quantitative Perspectives, Cambridge: Cambridge University Press, 1991.

Pollan, M. The Omnivore's Dilemma: A Natural History of Four Meals. New York: Penguin, 2007.

Qaim, M. Genetically Modified Crops and Agricultural Development. New York: PalgraveMacmillan, 2016.

Qaim, M. "Role of New Plant Breeding Technologies for Food Security and Sustainable Agricultural Development." Applied Economic Perspectives and Policy (2020) https://doi.org/10.1002/aepp.13044

Rao, X., T.M. Hurley and P.G. Pardey. "Are Agricultural R\&D Returns Declining and Development Dependent? World Development 122(2019a): 27-37.

Rao, X., T.M. Hurley and P.G. Pardey. "Recalibrating the Reported Returns to Agricultural R\&D: What if We All Heeded Griliches?” InSTePP Working Paper P19-07. St. Paul; University of Minnesota, Department of Applied Economics, $2019 \mathrm{~b}$.

Ruttan, V.W. Agricultural Research Policy. Minneapolis: University of Minnesota Press, 1982. 
Rausser, G., D. Zilberman, and G. Kahn. "An Alternative Paradigm for Food Production, Distribution, and Consumption: A Noneconomist's Perspective." Annual Review of Resource Economics 7(2015): 309-331. doi.org/10.1146/annurev-resource-100913-012549

Rausser, G., D. Zilberman, and S. Sexton. "The Economics of the Naturalist Food Paradigm," Annual Review of Resource Economics 11(2019): 217-236. doi.org/10.1146/annurevresource-100516-053623

Rasmussen, W.D. "The Impact of Technological Change on American Agriculture, 1862-1962." Journal of Economic History 22(4)(1962): 578-591.

Saitone, T., R. Sexton and D. Sumner. "What Happens When Food Marketers Require Restrictive Farming Practices?" American Journal of Agricultural Economics 97(4) (2015):1021-1043.

Saksena, M.J., A.M. Okrent, T.D. Anekwe, C. Cho, C. Dicken, A. Effland, H. Elitzak, J. Guthrie, K.S. Hamrick, J. Hyman, J. Young. America's Eating Habits: Food Away From Home. Washington, DC: U.S. Department of Agriculture - Economic Research Service, 2018.

Sexton, R.J. and T. Xia. "Increasing Concentration in the Agricultural Supply Chain: Implications for Market Power and Sector Performance." Annual Review of Resource Economics 10(2018): 229-51.

Schimmelpfennig, D. Farm Profits and Adoption of Precision Agriculture. Economic Research Report Number 217. Washington, D.C.: United States Department of Agriculture, 2016.

Schimmelpfennig, D. “Crop Production Costs, Profits, and Ecosystem Stewardship with Precision Agriculture. Journal of Agricultural and Applied Economics 50(1)(2018): 81103

Schimmelpfennig, D. and R Ebel. "Sequential Adoption and Cost Savings from Precision Agriculture." Journal of Agricultural and Resource Economics 41(1)(2016): 97-115.

Sumner, D.A. “American Farms Keep Growing: Size, Productivity, and Policy.” Journal of Economic Perspectives 28(1)(2014): 147-166.

Taylor, N.J. and C.M. Fauquet. "Microparticle Bombardment as a Tool in Plant Science and Agricultural Biotechnology.” DNA and Cell Biology 21 (12)(2002): 963-977.

Teralytic. "Soil Probes to Soil Insight." 2020. Available at https://teralytic.com/how-itworks.html.

United Nations Statistics Division. UN National Accounts Main Aggregates Database. New York: United Nations. 2017. Downloaded on January 25th 2017 from http://unstats.un.org/unsd/snaama/dnlList.asp. Data was uploaded by the UN on December 2016.

USDA-CRIS (Current Research Information System). "Unpublished 2015 CRIS data files, authors extraction." Washington, D.C.: United States Department of Agriculture, Current Research Information System, 2020.

USDA-ERS (U.S. Department of Agriculture, Economic Research Service). Economic Indicators of the Farm Sector: Production and Efficiency Statistics, 1981. ECIFS 1-3, Washington, D.C.: USDA, Economic Research Service, 1983. 
USDA-NASS. Farm Producers. 2017 Census of Agriculture Highlights. Washington, DC:

United States Department of Agriculture, 2019. Available at

https://www.nass.usda.gov/Publications/Highlights/2019/2017Census_Farm_Producers.pdf

USDA-NASS. Census of Agriculture. United States, Summary and State Data. Washington, DC: United States Department of Agriculture. (various years). Available at http://agcensus.mannlib.cornell.edu/AgCensus/

USDA-ERS (U.S. Department of Agriculture, Economic Research Service). Food Dollar Series. Washington, D.C.: USDA, Economic Research Service, March 2019. www.ers.usda.gov/data-products/food-dollar-series/.

U.S. Department of Commerce, Bureau of the Census. 1969 Census of Agriculture - Volume II General Report, Chapter 1 General Information, Procedures for Collection, Processing, Classification. U.S. Department of Commerce. Washington, DC: Government Printing Office. 1973 U.S.

U.S. Department of Commerce, Bureau of the Census. 1974 Census of Agriculture - United States Summary and State Data, Volume I Part 51. U.S. Department of Commerce. Washington, DC: Government Printing Office. 1977.

U.S. Department of Commerce, Bureau of Census. Census of Agriculture. United States, Summary and State Data. Washington, DC: Government Printing Office. (various years) Available at http://agcensus.mannlib.cornell.edu/AgCensus/.

Van Eenennaam, A.L. "Application of Genome Editing in Farm Animals: Cattle." Transgenic Research 28 (2019):93-100.

Wight, A.J. "EU Gene-Editing Rule Squeezes Science.” Nature 563 (2018):15.

Willett, W., J. Rockström, B. Loken, M. Springmann, T. Lang, S. Vermeulen, T. Garnett, D. Tilman, F. DeClerck, A. Wood, M. Jonell, M. Clark, L.J. Gordon, J. Fanzo, C. Hawkes, R. Zurayk, J.A. Rivera, W. De Vries, L.M. Sibanda, and A. Afshin. "Food in the Anthropocene: The EAT-Lancet Commission on Healthy Diets from Sustainable Food Systems." The Lancet 393.10170 (2019): 447-92.

World Bank. World Development Indicators Online. Washington, D.C.: World Bank, 2017. Downloaded January $25^{\text {th }} 2017$ from http://data.worldbank.org/data-catalog/worlddevelopment-indicators. (last updated January 3rd 2017)

Wright, B.D. "Grand Missions of Agricultural Innovation." Research Policy 41(2012) 17161728. http://dx.doi.org/10.1016/j.respol.2012.04.021

Wright, B.D. and P.G. Pardey. "The Evolving Rights to Intellectual Property Protection in the Agricultural Biosciences." International Journal for Technology and Globalization 2(1/2) (2006): 12-29. 
Figure 1: U.S. farm area and farm numbers, 1850-2017

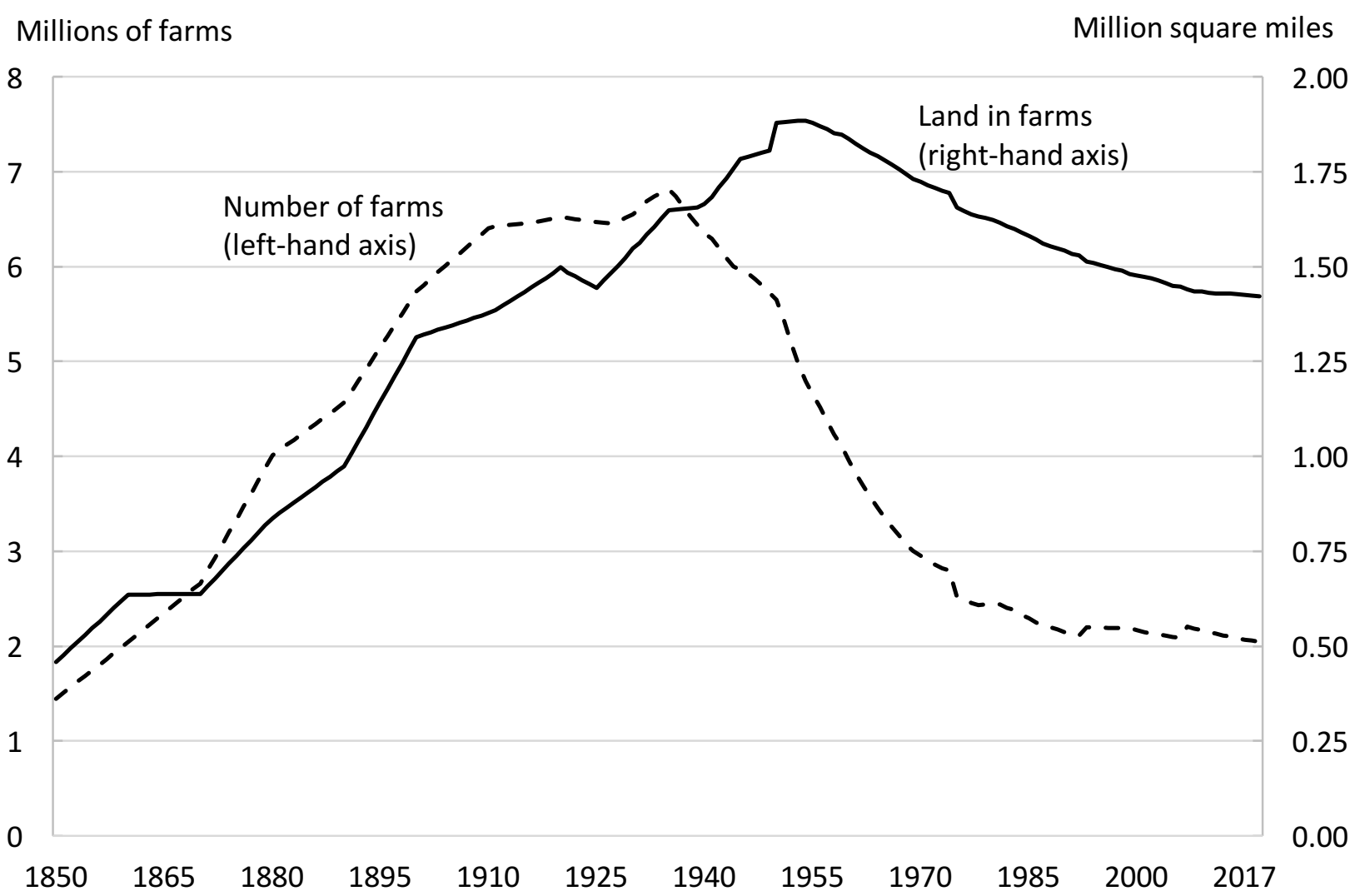

Sources: Pardey and Alston (2019, Figure 4).

Notes: For number of farms, missing intercensal values were estimated by linear interpolation. 
Figure 2: Labor use in U.S. agriculture, 1949-2012

\section{Panel a: Structure of labor}

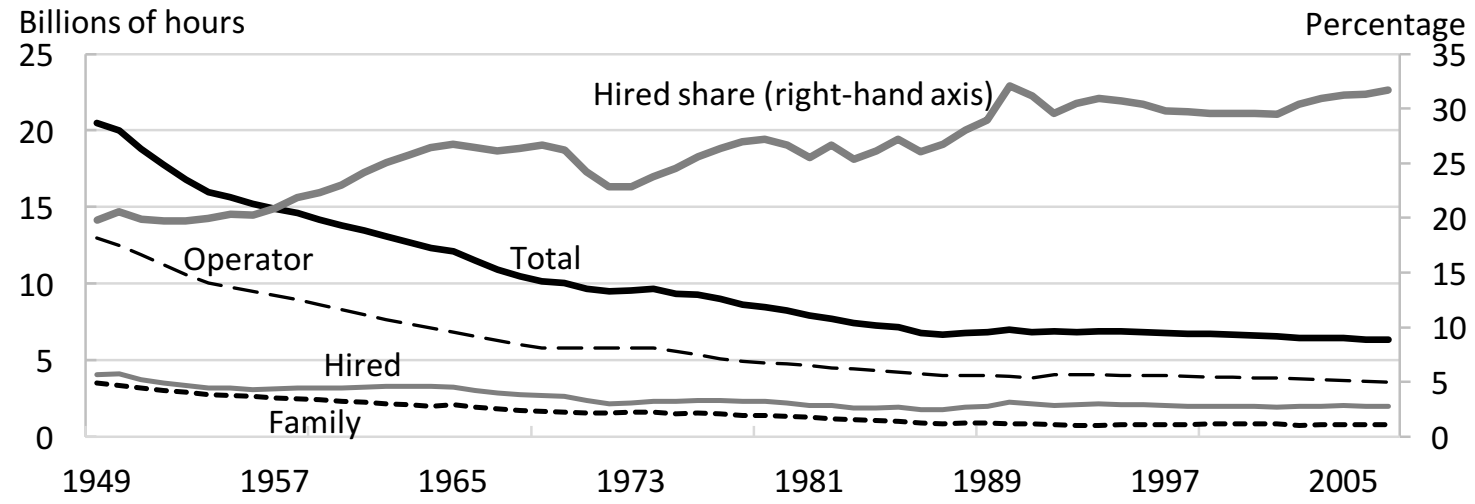

\section{Panel b: Labor and other cost shares}

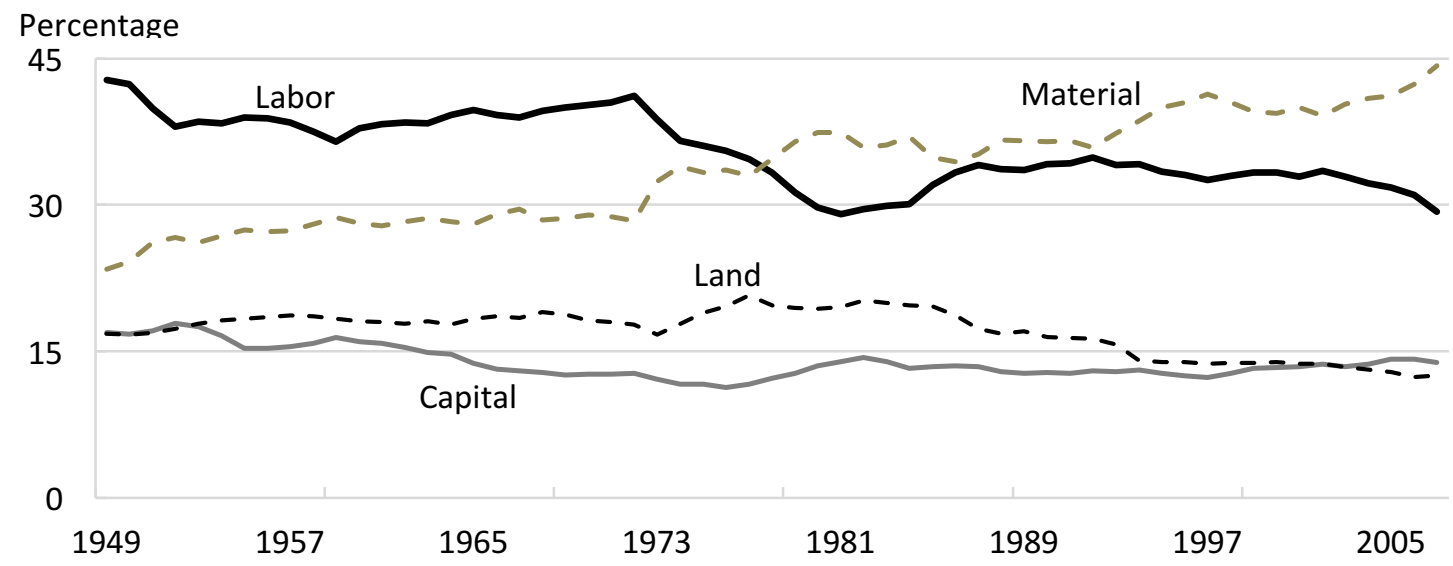

\section{Panel c: Part time farm operators}

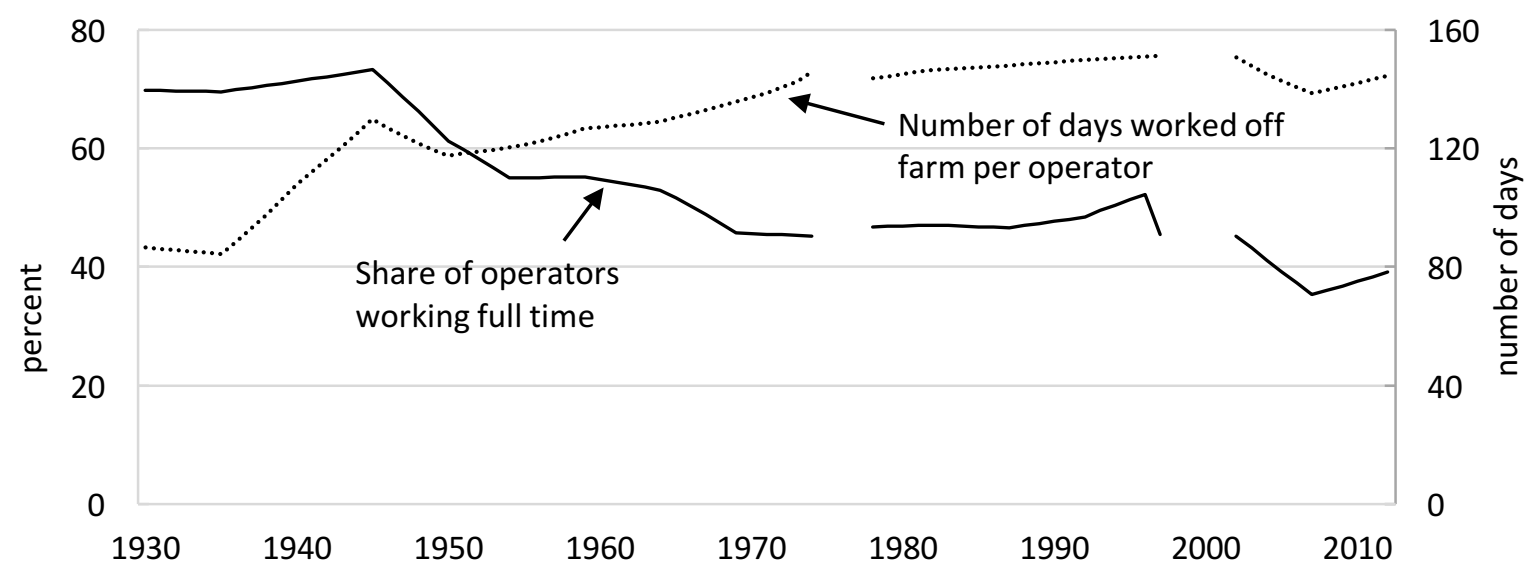

Sources: Pardey and Alston (2019, Figure 6).

Notes: In all census years up to 1997, the reported number of operators was set equal to the total number of farms. From 2002 onwards the census reported information on the total number of operators. If a farm had more than one operator, it was counted accordingly. 
In all census years up to 1997, data are reported in terms of operators by days worked off-farm cohorts (e.g., 0 days, 1-49 days, 50-99 days etc.). For 2002, 2007, and 2012, data are reported in terms of cohorts of days worked offfarm by the principal operator. In 1974, data were collected only for individual or family operations (sole proprietorships) and partnerships. Thus, corporations and other types of organizations (e.g., cooperative, prison farms, grazing associations, and Indian reservations) were excluded (for more details, see U.S. Bureau of Census, 1977, Appendix A, page A4). In all other years, data on days worked off-farm were collected for all types of farms.

To calculate the average number of days worked off-farm per operator, we proceeded as follows. First, the total number of days worked off-farm in each cohort was estimated by multiplying the mid-point number of days worked off farm in each cohort (e.g., 25 days for 1-49 days, 75 days for 50-99 days etc. and 200 days for 200 and more) by the corresponding total number of operators. The total number of days worked off farms was obtained by summing the estimated number of days worked off-farm across cohorts. The number of days worked off-farm per operator is given by the total number of days worked off-farm divided by the total number of operators.

Data for intercensal years were estimated by linear interpolation.

The total number of operators working full time was estimated by subtracting the number of operators working offfarms from the total number of operators. 
Table 1: Growth rates in U.S. agricultural input, output, and productivity 1910-2007

\begin{tabular}{lccccc}
\hline \multirow{2}{*}{ Period } & \multirow{2}{*}{ Input } & Output & \multicolumn{4}{c}{ Productivity Indexes } \\
\cline { 4 - 6 } & & \multicolumn{5}{c}{ MFP } & Labor & Land \\
\hline & 0.46 & 1.47 & 1.01 & 2.16 & 0.50 \\
$1910-1950$ & -0.21 & 1.76 & 1.97 & 4.07 & 1.92 \\
$1950-1990$ & 0.31 & 1.39 & 1.08 & 1.90 & 2.04 \\
$1990-2007$ & & & & & \\
$1910-2007$ & 0.16 & 1.58 & 1.42 & 2.90 & 1.35 \\
\hline
\end{tabular}

Notes: All figures are annual averages of year-to-year changes.

Source: Growth rates of productivity indexes were calculated by the authors using the InSTePP Production Accounts, version 5, augmented with data from USDA-ERS (1983). See Pardey and Alston (2019). 
Figure 3: Top 4, 8, and 20 firms' shares of U.S. grocery store sales, 1992-2016

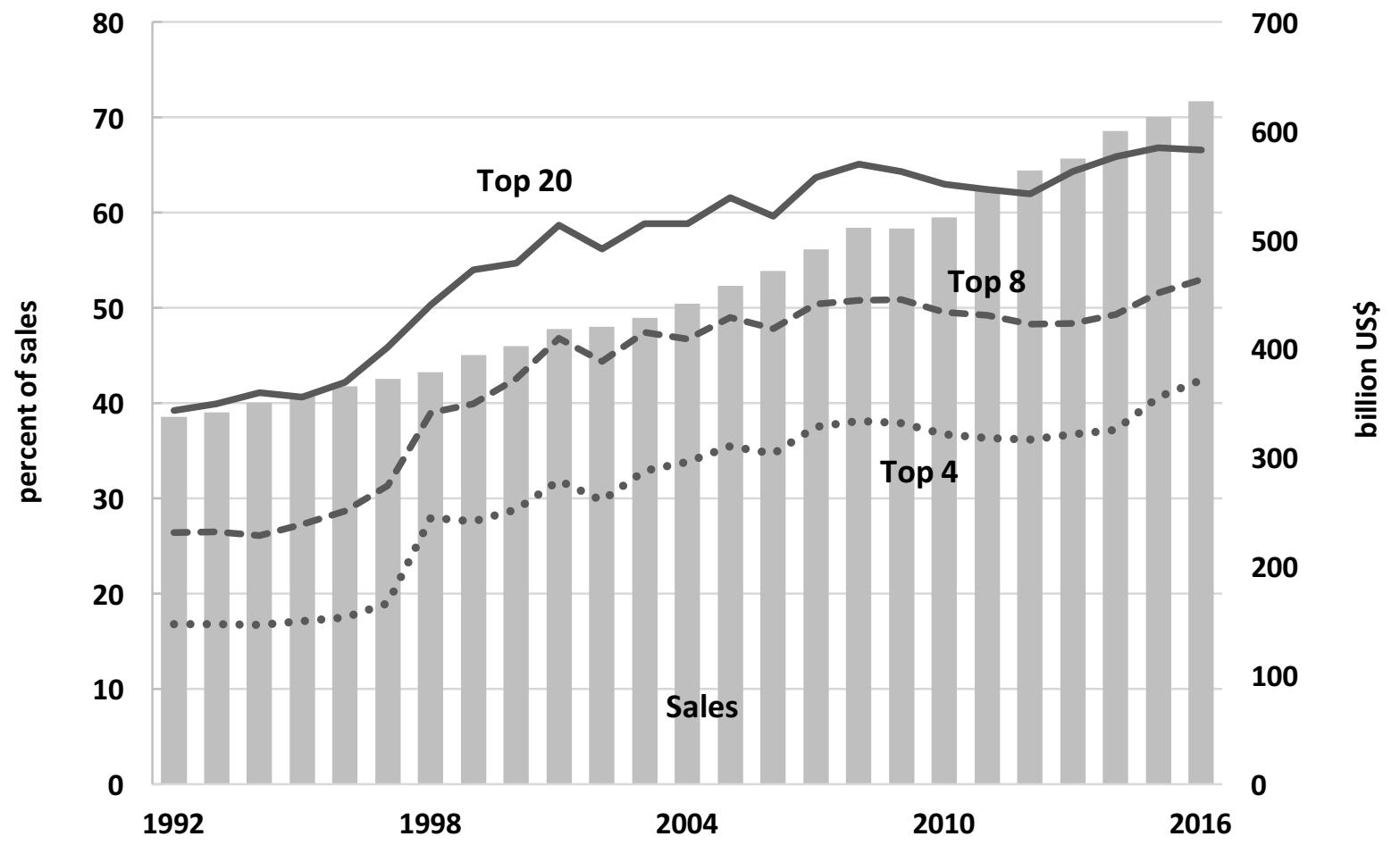

Sources: USDA, Economic Research Service, using data from U.S. Census Bureau, Monthly Retail Trade Survey, company annual reports, and industry sources. Sales based on North American Industry Classification System (NAICS). 
Figure 4: Food expenditures at home and away from home, 1988 and 2018

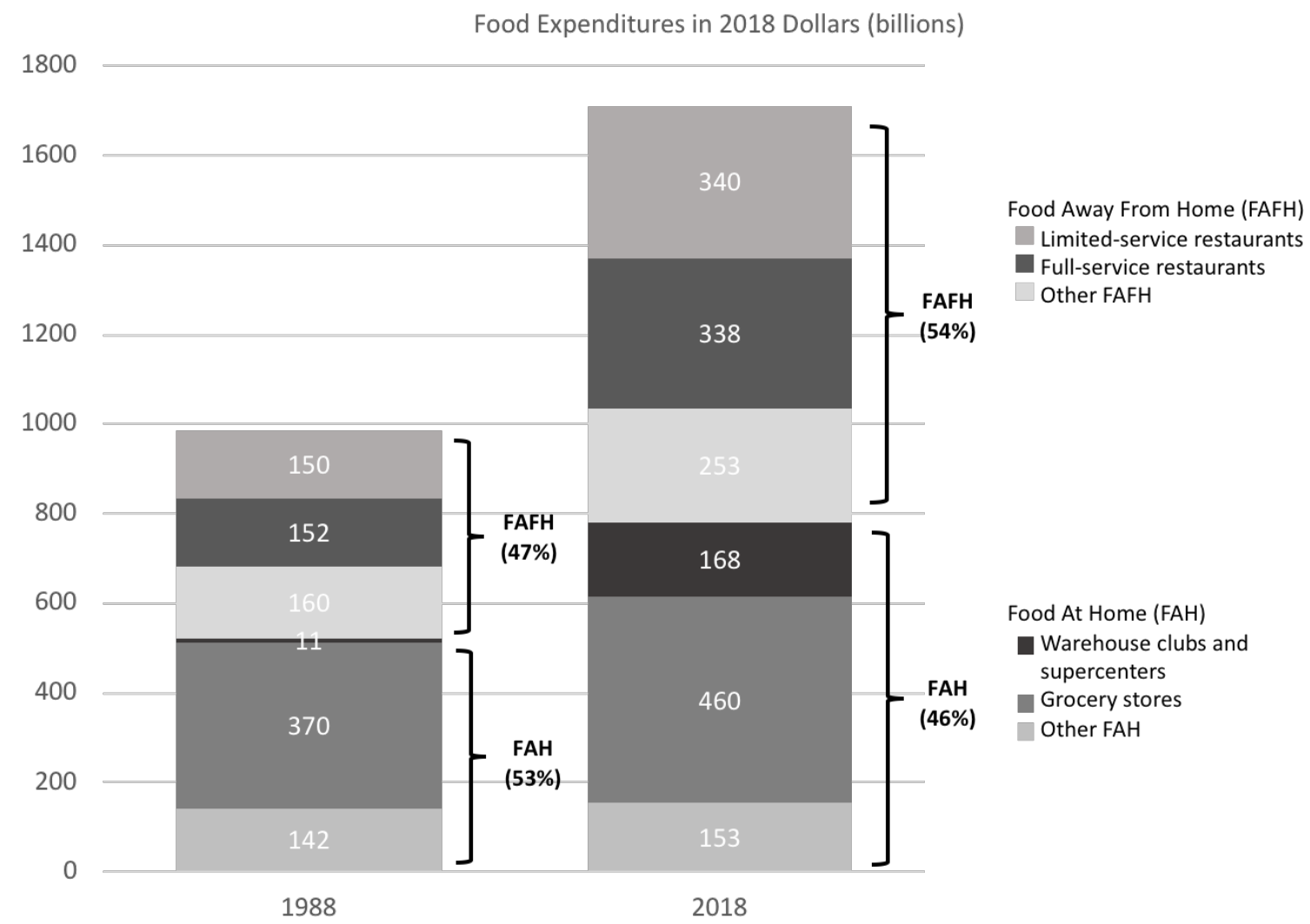

Sources: Calculated by USDA, Economic Research Service, from various sources. See details in Okrent et al. (2018).

Notes: Nominal 1988 values inflated to 2018 values using CPI data from the U.S. Bureau of Labor Statistics: https://www.bls.gov/data/inflation_calculator.htm 
Figure 5: GERD versus agGERD trends, 1950-2015

Panel a: GERD

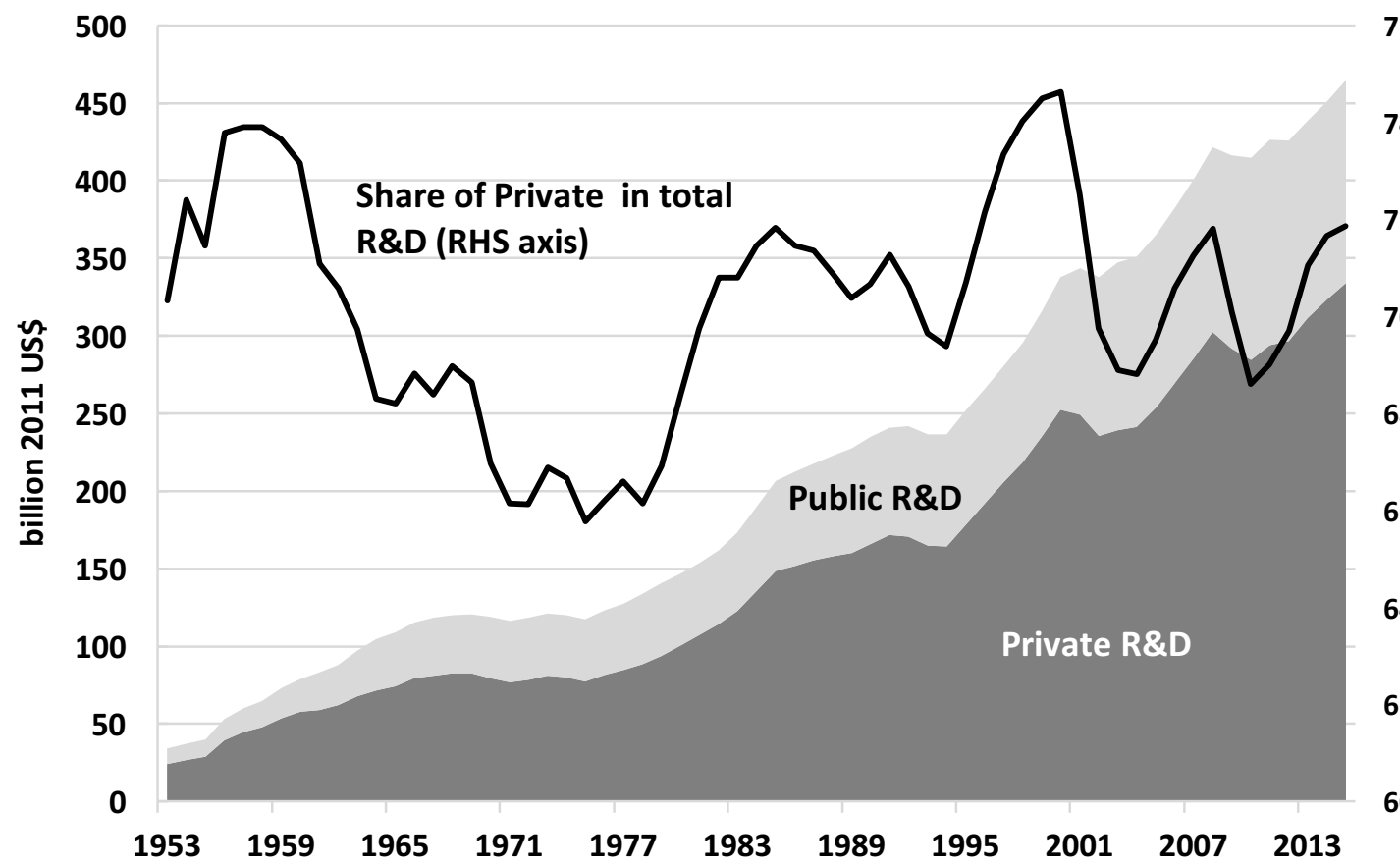

Panel b: AgGERD

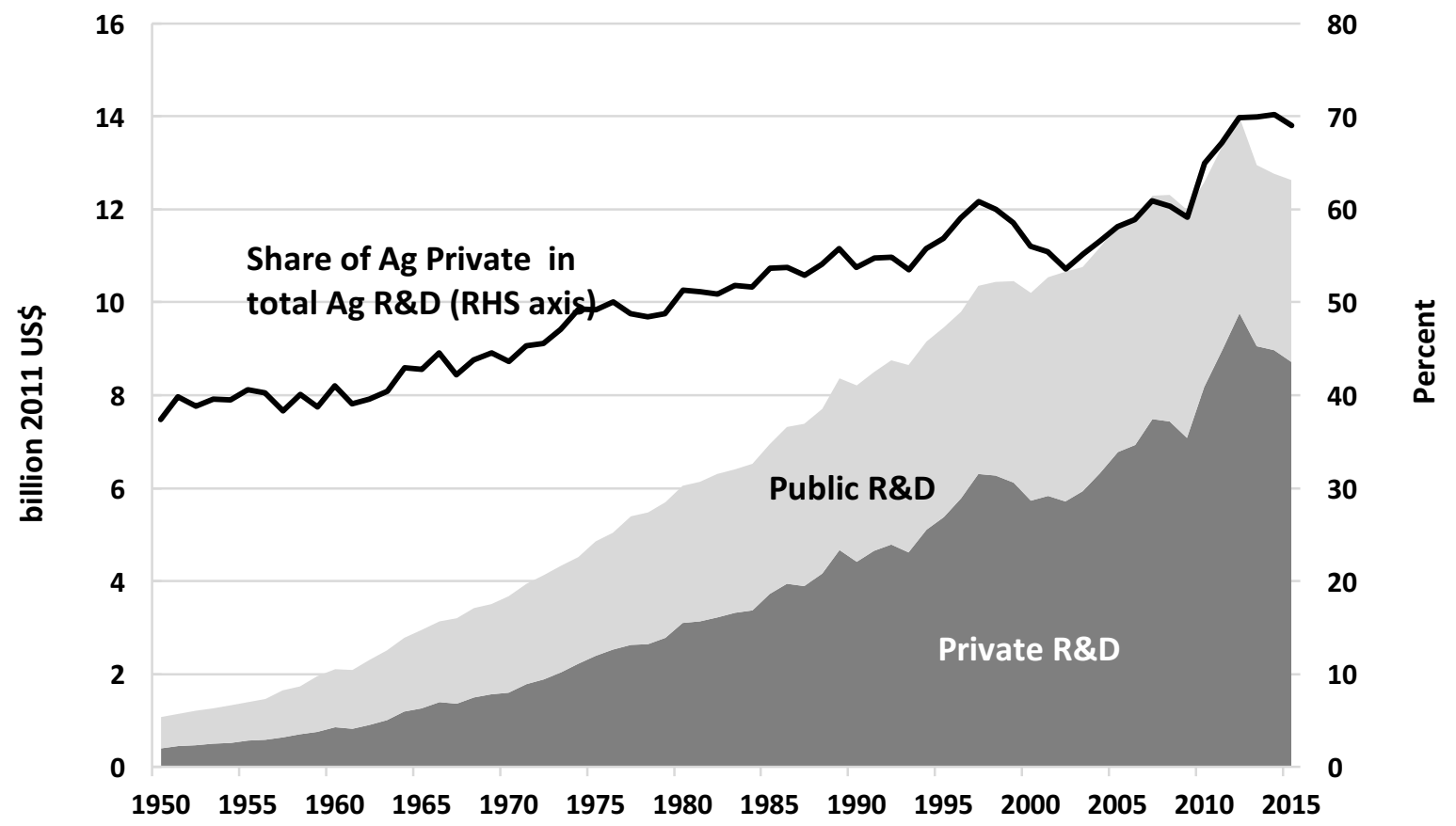

Sources: GERD data are from NSF (2019); AgGERD data are from InSTePP International Innovation Accounts: Research and Development Spending (2019).

Notes: Public GERD include R\&D expenditures from federal, non-federal, higher education and other non-profit organization. 
Figure 6: The intensity of investment in GERD versus agGERD, 1950-2015

Panel a: GERD, BERD, and PERD as a share of GDP

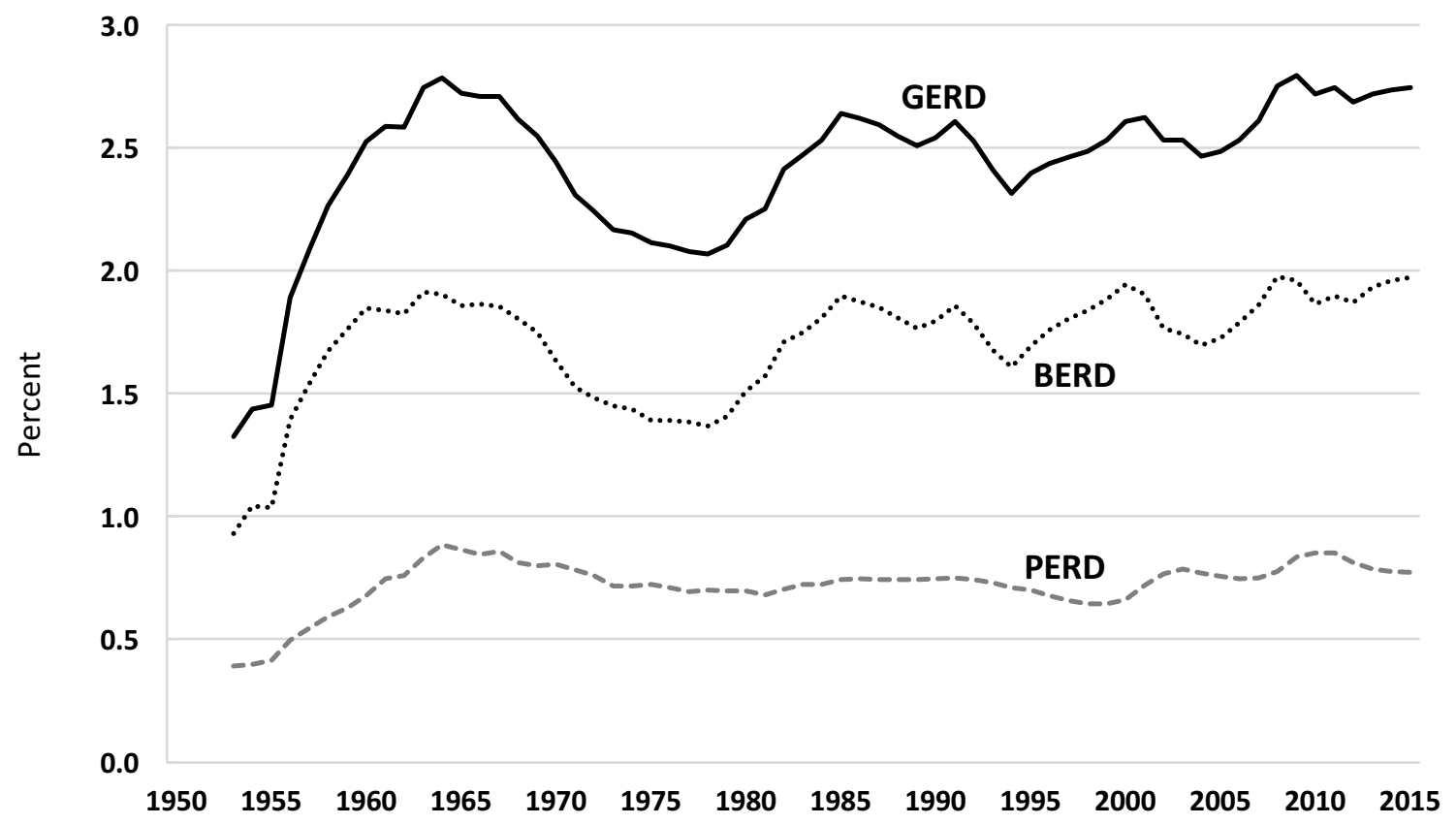

Panel b: AgGERD, AgBERD, and AgPERD as a share of AgGDP

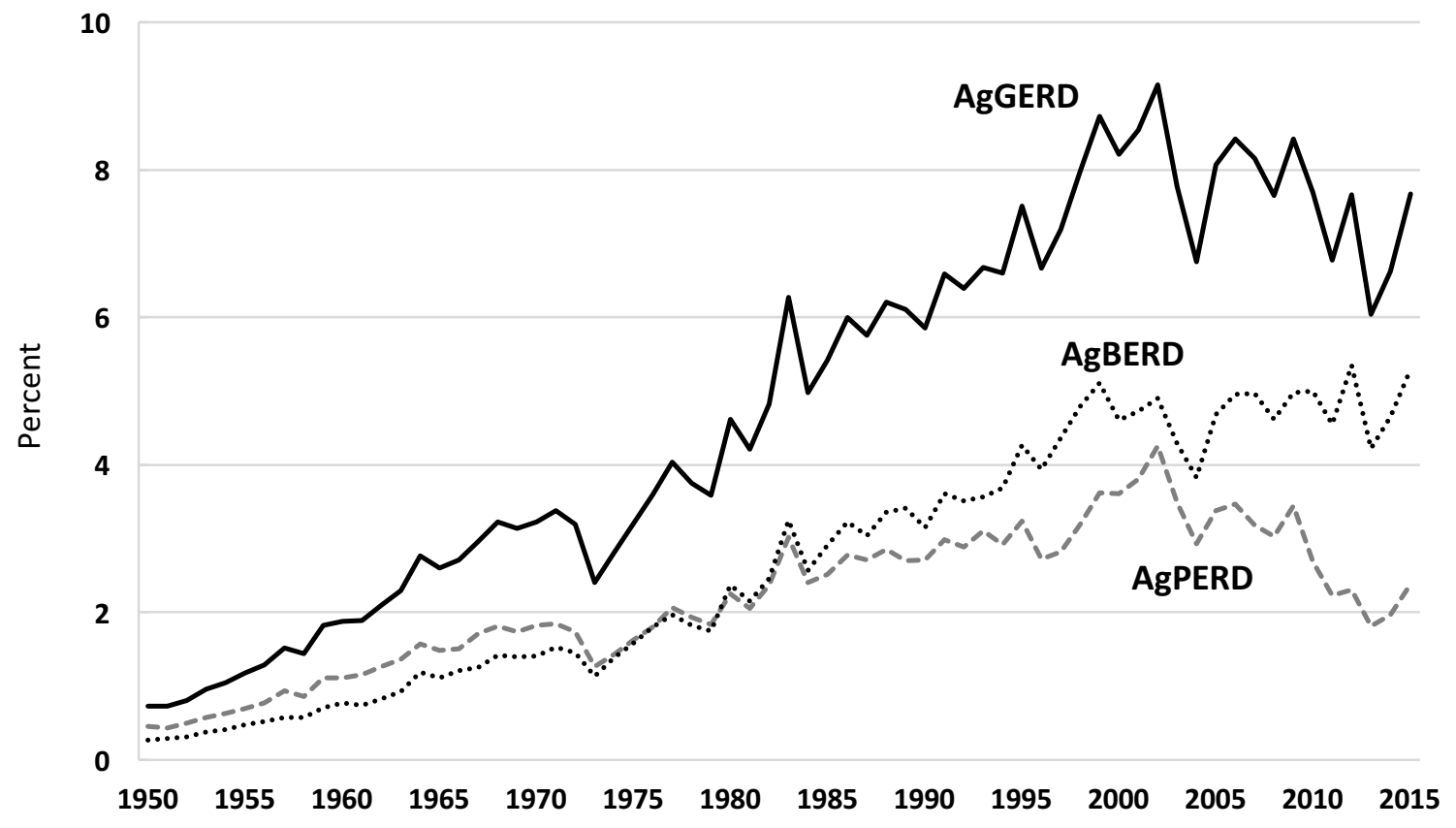

Sources: GERD (total), BERD (business) and PERD (Public) R\&D spending data are from NSF (2018); AgGERD, AgBERD and AgPERD data are from InSTePP International Innovation Accounts: Research and Development Spending (2019); GDP data are authors' compilation based on data from UN (2017), World Bank (2017) and Johnston and Williamson (2017); AgGDP data are authors' compilation based on data from UN (2017), and BEA (2017). 
Table 2: Company sales and R\&D intensity, 2014/15

\begin{tabular}{lcrr}
\hline & Sales & $\begin{array}{c}\text { R\&D } \\
\text { Expenditures }\end{array}$ & R\&D Intensity \\
\hline & (millions of dollars) & (percentage) \\
Manufacturing Industries & & & \\
$\quad$ Chemicals & $\mathbf{5 , 3 5 8 , 5 4 2}$ & $\mathbf{2 3 5 , 7 7 6}$ & $\mathbf{4 . 4}$ \\
$\quad$ Pharmaceuticals and medicines & $1,023,512$ & 68,575 & 6.7 \\
$\quad$ Others & 456,424 & 58,879 & 12.9 \\
Machinery & 567,088 & 9,640 & 1.7 \\
Automobiles, trailers and parts & 360,719 & 13,347 & 3.7 \\
Others & 795,662 & 19,096 & 2.4 \\
& $1,901,685$ & 28,525 & 1.5 \\
Non-manufacturing industries & & & $\mathbf{3 . 2}$ \\
Information & $\mathbf{3 , 6 9 1 , 3 5 8}$ & $\mathbf{1 1 8 , 1 2 3}$ & 5.9 \\
Finance and insurance & $1,105,520$ & 65,226 & 0.8 \\
Others & 709,990 & 5,680 & 0.7 \\
& $1,453,882$ & 10,177 & $\mathbf{3 . 9}$ \\
All industries & & & $\mathbf{1 . 2}$ \\
Food and Agriculture & $\mathbf{9 , 0 4 9 , 9 0 1}$ & $\mathbf{3 5 2 , 9 4 6}$ & 0.7 \\
Food & & & 2.6 \\
Agriculture (machinery, chemicals and & $\mathbf{7 6 7 , 8 5 7}$ & $\mathbf{9 , 4 4 7}$ & 3,821 \\
biology) & 554,237 & 5,626 & \\
\hline
\end{tabular}

Sources: Manufacturing, non-manufacturing and all industries data are from National Science Board (2018, Table 4.10); Food and Agriculture data are from Lee et al. (2020) taken from InSTePP International Innovation Accounts: Research and Development Spending (2019)

Notes: Sales from manufacturing and non-manufacturing industries includes domestic net sales of companies that perform or fund $\mathrm{R} \& \mathrm{D}$, transfers to foreign subsidiaries, and export sales to foreign companies; excludes intracompany transfers and sales by foreign subsidiaries. $R \& D$ intensity from manufacturing and non-manufacturing industries represent domestic R\&D paid for by the company and others and performed by the company divided by domestic net sales. 
Table 3: Returns to agricultural R\&D

\begin{tabular}{|c|c|c|c|c|c|c|c|}
\hline & \multirow[b]{2}{*}{ Units } & \multicolumn{2}{|c|}{ Number of } & \multicolumn{4}{|c|}{ Values } \\
\hline & & Studies & Estimates & $\begin{array}{c}\text { 10th } \\
\text { percentile }\end{array}$ & Mean & Median & $\begin{array}{c}90 \% \\
\text { percentile }\end{array}$ \\
\hline \multicolumn{8}{|l|}{ Reported Data } \\
\hline \multicolumn{8}{|l|}{ United States } \\
\hline Internal rate of return & $\%$ per year & 80 & 986 & 12.5 & 63.0 & 31.9 & 101.2 \\
\hline Benefit-cost ratio & Ratio & 21 & 312 & 0.5 & 19.3 & 12.0 & 45.0 \\
\hline \multicolumn{8}{|l|}{ Rest of world } \\
\hline Internal rate of return & $\%$ per year & 381 & 1,641 & 16.0 & 57.6 & 41.2 & 101.0 \\
\hline Benefit-cost ratio & Ratio & 147 & 487 & 1.7 & 31.4 & 12.1 & 69.6 \\
\hline \multicolumn{8}{|l|}{ Imputed Data $(\delta=5 \%)$} \\
\hline \multicolumn{8}{|l|}{ United States } \\
\hline Benefit-cost ratio & Ratio & 66 & 796 & 2.1 & 34.4 & 7.5 & 44.6 \\
\hline Modified internal rate of return & $\%$ per year & 66 & 796 & 7.7 & 11.4 & 12.3 & 19.2 \\
\hline \multicolumn{8}{|l|}{ Rest of world } \\
\hline Benefit-cost ratio & Ratio & 345 & 1,330 & 2.6 & 25.7 & 9.0 & 57.3 \\
\hline Modified internal rate of return & $\%$ per year & 345 & 1,330 & 8.4 & 13.6 & 13.0 & 20.2 \\
\hline
\end{tabular}

Sources: Derived from InSTePP compilation used by Rao et al. (2019 a and b). 
Figure 7: American agricultural mechanization, 1867-2012

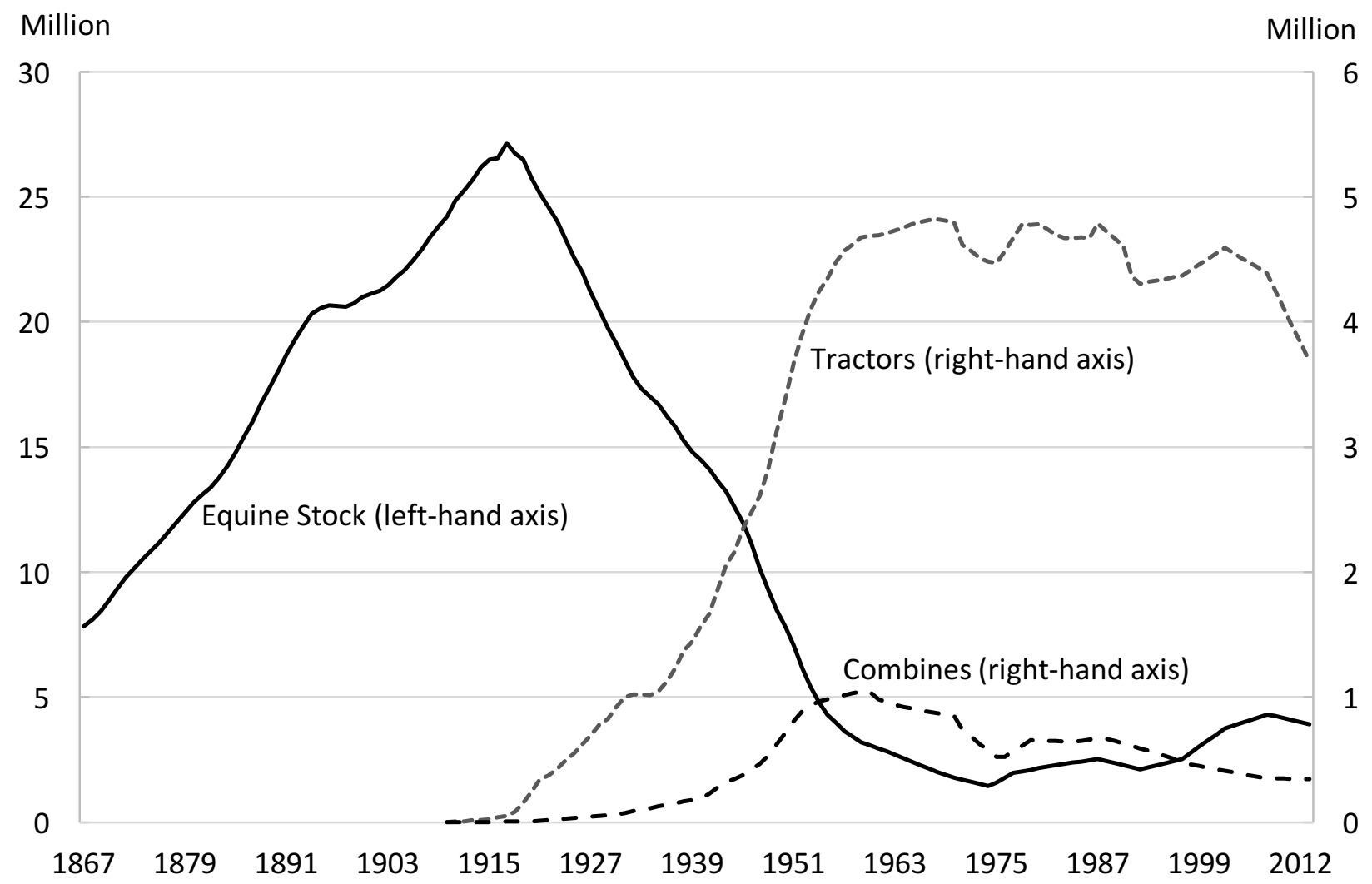

Sources: Pardey and Alston (2019, Figure 5)

Notes: See Alston et al. (2010, page 29) for notes on equine stock. 
Figure 8: Waves of technological adoption in U.S. agriculture

Panel a: Mechanical, chemical and conventional genetic improvement technologies

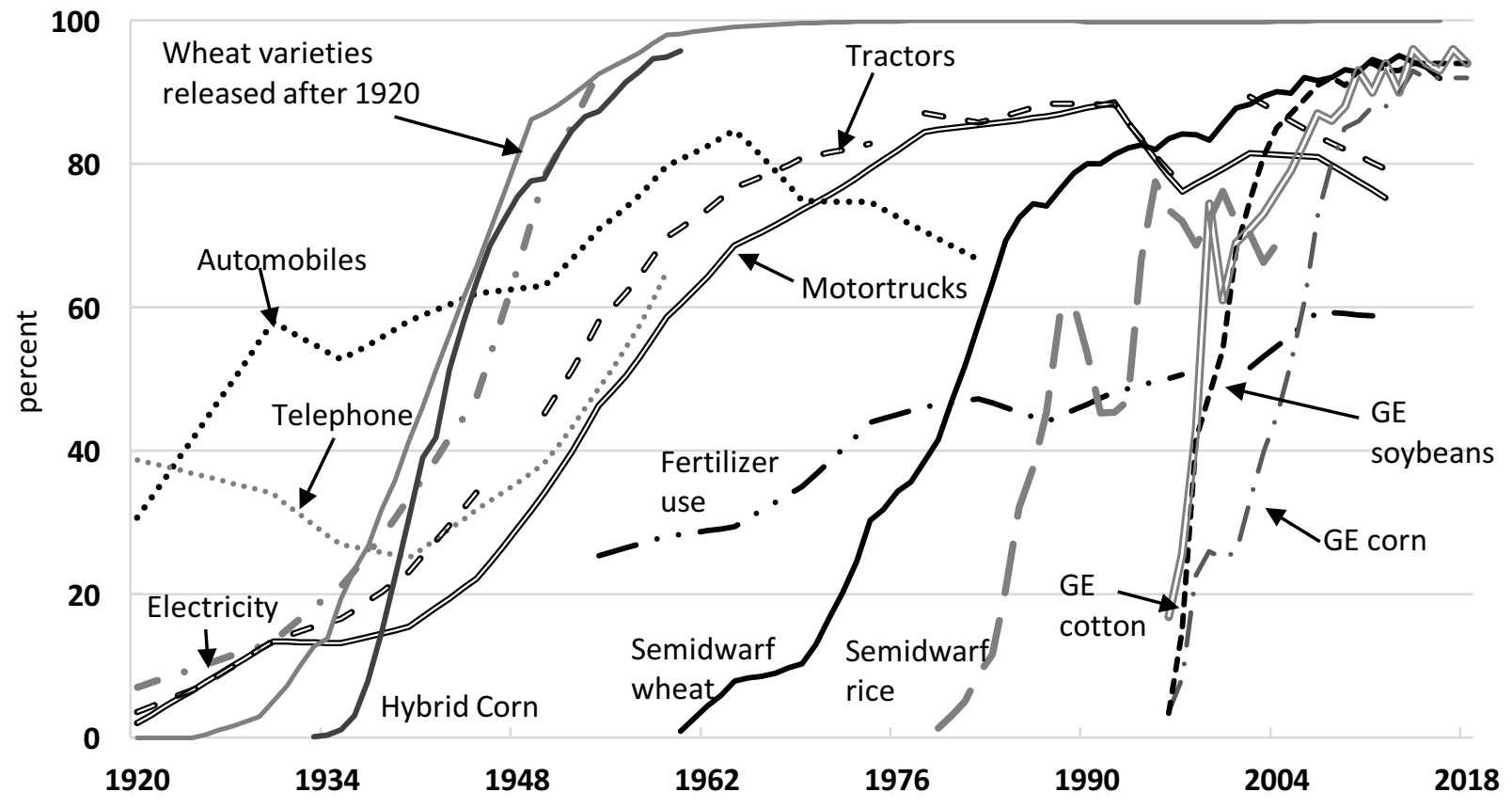

Panel b: Modern genetic transformation technologies and precision agriculture technologies

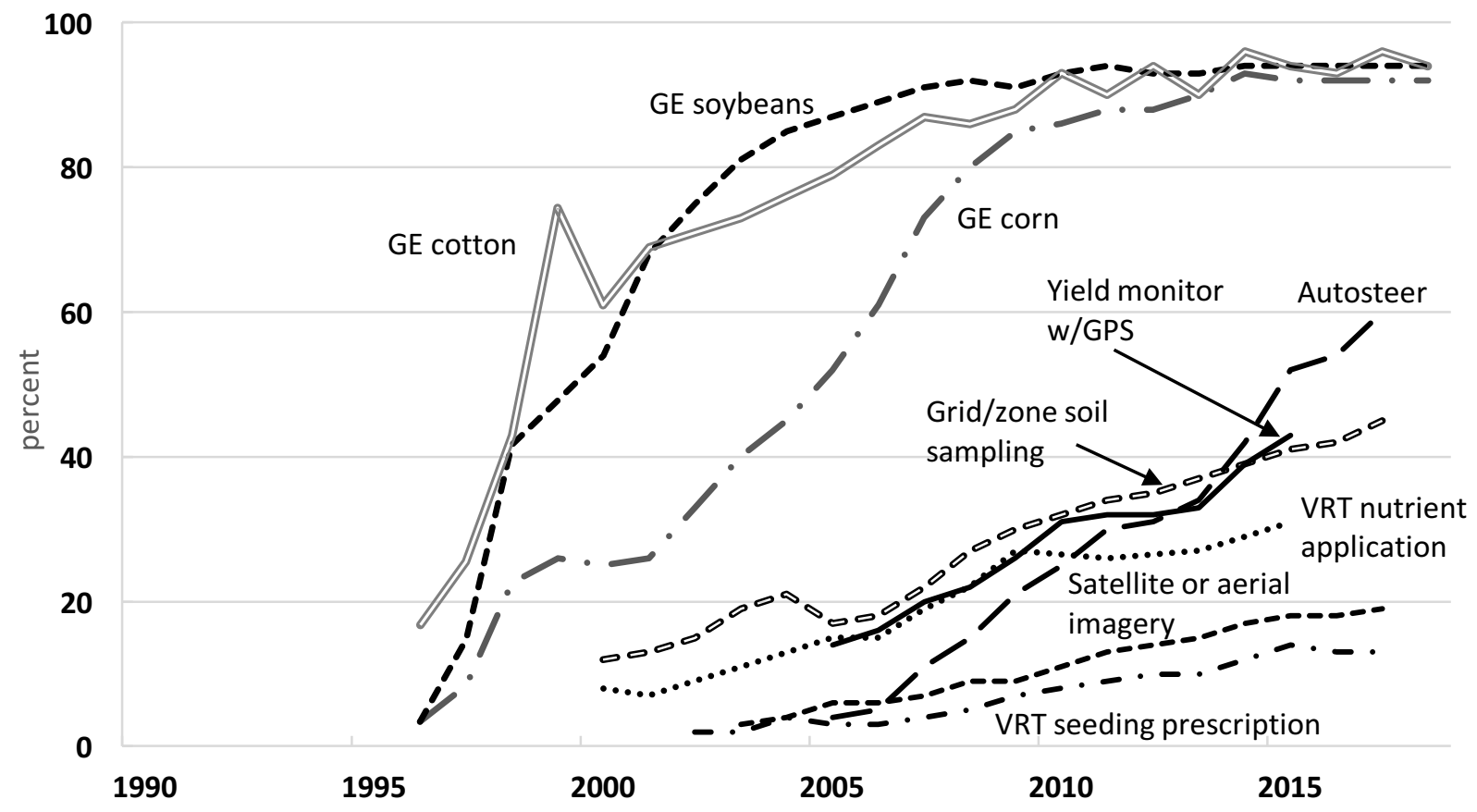

Sources: Mechanical, infrastructure and fertilizer data were developed by authors based on estimates from the U.S. Census of Agriculture (Bureau of Census and USDA-NASS, various years). Data for intercensus years were linearly interpolated. Data on hybrid corn are from Alston et al. (2010); GE soybeans, GE corn, and GE cotton data are from Alston et al. (2010) and USDA-NASS "June Agricultural Survey" available at www.ers.usda.gov/dataproducts/adoption-of-genetically-engineered-crops-in-the-us/. Semidwarf wheat and rice areas and area of wheat varieties released after 1920 are unpublished data from InSTePP. Estimated precision agriculture technologies cropland area shares are from Erickson et al. (2017). 
Notes: For automobiles, motor trucks, tractors, electricity, and telephone, the data represent the shares of farms using the designated technology. For hybrid corn, semidwarf rice, semidwarf wheat, GE soybeans and GE corn, the data represent the shares of area planted to the designated technology. For fertilizer, the data represent the share of cropland with fertilizer application. For precision agriculture technologies (autosteer, yield monitor with GPS, grid/zone soil sampling, satellite or areal imagery, VRT nutrient application, and VRT seeding prescription) data represent the share of the market area of various precision ag technologies used by farmers.

Tractors: From 1920 to 1945, tractors include wheel, crawler, and garden; from 1950 to 1969, tractors include wheel and crawler; from 1978 to 1997, tractors include wheel tractor only; from 2002 to 2012, tractors include wheel and crawler.

Automobiles: Details concerning the sudden and sustained drop in the number of automobiles in 1969 are reported in US Department of Commerce, Bureau of Census (1973, p. 11).

Fertilizer: From 1954 to 1997 fertilizer do not include lime whereas from 2002 to 2012 lime is included. Manure is excluded in all years. From 1978 to 2012, acres on which fertilizers were applied are reported for cropland only, pastureland, and total (i.e., cropland and pastureland). In 1959, 1964, 1969 and 1974 however, data were reported for pastureland and total acres fertilized. Thus, acres of cropland fertilized were estimated for those years by subtracting acres of pastureland fertilized from total acres fertilized. In 1954, only data on total acres fertilized was available. Thus, we estimated the area of cropland fertilized in 1954 by applying the share of cropland fertilized in 1959 to the 1954 cropland area. 
Appendix Figure A-1: Quantity indexes of output, input, and MFP, U.S. agriculture, 19102007

Index (1910=100)

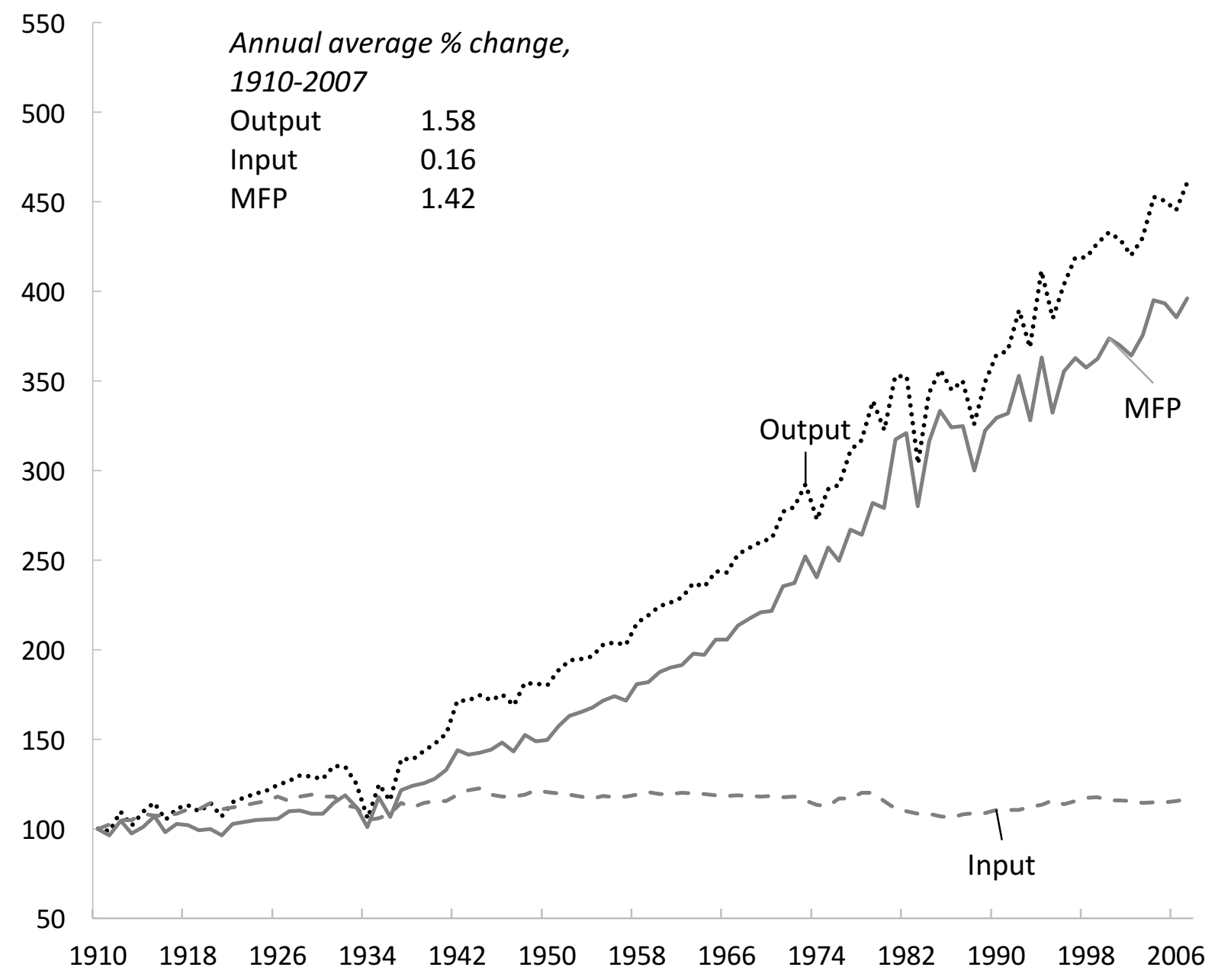

Sources: Pardey and Alston (2019, Figure 1). 
Appendix Table A-1: Food expenditures at home and away from home, 1988 and 2018

\begin{tabular}{|c|c|c|c|c|}
\hline & & $\begin{array}{c}1988 \\
\text { (Nominal) }\end{array}$ & $\begin{array}{c}1988 \\
\text { (Inflated)* }\end{array}$ & 2018 \\
\hline \multicolumn{5}{|l|}{$\mathrm{FAH}$} \\
\hline & Grocery Stores & 177.9 & 385.9 & 460.0 \\
\hline & $\begin{array}{l}\text { Warehouse clubs and } \\
\text { supercenters }\end{array}$ & 5.1 & 11.1 & 168.0 \\
\hline & Other & 68.4 & 148.4 & 153.0 \\
\hline & Total & 251.3 & 545.4 & 780.9 \\
\hline \multicolumn{5}{|l|}{ FAFH } \\
\hline & Full-service restaurants & 73.1 & 158.7 & 337.8 \\
\hline & $\begin{array}{l}\text { Limited-service } \\
\text { restaurants }\end{array}$ & 72.2 & 156.7 & 340.2 \\
\hline & Other & 76.7 & 166.5 & 252.6 \\
\hline & Total & 222.1 & 481.9 & 930.6 \\
\hline
\end{tabular}

*Calculated using CPI data from the U.S. Bureau of Labor Statistics: https://www.bls.gov/data/inflation_calculator.htm

Source: Calculated by USDA, Economic Research Service, from various sources. See Okrent et al. (2018) for details. 


\section{Appendix Table A-2: Regional growth in U.S. agricultural inputs, outputs, and productivity}

\begin{tabular}{|c|c|c|c|c|c|c|c|c|}
\hline & $\begin{array}{l}\text { United } \\
\text { States }\end{array}$ & Pacific & Mountain & N. Plains & S. Plains & Central & Southeast & Northeast \\
\hline & \multicolumn{8}{|c|}{ annual average growth rate } \\
\hline All Inputs & -0.11 & 0.82 & 0.45 & 0.16 & -0.12 & -0.27 & -0.41 & -0.84 \\
\hline Land & -0.10 & 0.59 & 0.41 & -0.13 & 0.21 & -0.51 & 0.29 & -0.67 \\
\hline Labor & -1.74 & -0.47 & -0.90 & -1.64 & -1.80 & -1.92 & -2.15 & -2.26 \\
\hline Capital & -0.07 & 0.08 & 0.02 & 0.25 & 0.13 & -0.06 & -0.74 & -1.16 \\
\hline Materials & 1.88 & 2.58 & 2.35 & 2.09 & 2.05 & 1.57 & 2.29 & 0.65 \\
\hline All Outputs & 1.68 & 2.50 & 1.97 & 2.12 & 1.66 & 1.44 & 1.63 & 0.84 \\
\hline Livestock & 1.39 & 2.32 & 2.03 & 1.44 & 2.16 & 0.44 & 2.34 & 0.78 \\
\hline Field Crops & 1.65 & 0.76 & 1.00 & 2.60 & 0.95 & 2.29 & 0.27 & 0.60 \\
\hline Specialty Crops & 2.21 & 2.82 & 2.60 & 1.20 & 1.55 & 1.62 & 2.36 & 0.60 \\
\hline \multicolumn{9}{|c|}{ Multi-Factor Productivity } \\
\hline 1949-2002 & 1.78 & 1.82 & 1.59 & 1.89 & 1.88 & 1.61 & 2.09 & 1.64 \\
\hline 1949-1990 & 2.02 & 2.02 & 1.89 & 2.31 & 2.01 & 1.70 & 2.49 & 2.16 \\
\hline 1990-2002 & 0.97 & 1.15 & 0.57 & 0.43 & 1.47 & 1.30 & 0.72 & -0.14 \\
\hline
\end{tabular}

Sources: InSTePP production accounts.

Notes: Average annual growth rates for inputs and multi-factor productivity span the period 1949-2002; for outputs they span the period 1949-2006. 